\title{
Tropospheric Ozone in Tehran, Iran, during the last 20 years
}

\author{
Faezeh Borhani (D) Majid Shafiepour Motlagh • Andreas Stohl $\mathbb{D} \cdot$ \\ Yousef Rashidi • Amir Houshang Ehsani
}

Received: 30 June 2021 / Accepted: 27 September 2021 / Published online: 18 October 2021

(C) The Author(s), under exclusive licence to Springer Nature B.V. 2021

\begin{abstract}
Air pollution and its effects on human health and the environment are one of the main concerns in urban areas. This study focuses on the distribution and changes in the concentrations of ozone and its precursors (i.e., $\mathrm{NO}, \mathrm{NO}_{2}$ and $\mathrm{CO}$ ) in Tehran for the 20-year period from 2001 to 2020. The effects of precursors and meteorological conditions (temperature, wind speed, dew point, humidity and rainfall) on ozone were investigated using data from 22 stations of the Air Quality Control Company (AQCC) and meteorological stations. Regression models were applied to evaluate the dependence of ozone concentration on its precursors and meteorological parameters based on monthly average values.
\end{abstract}

F. Borhani $(\bowtie) \cdot$ M. Shafiepour Motlagh · A. H. Ehsani School of Environment, College of Engineering, University of Tehran, P.O. Box, 14155-6135 Tehran, Iran e-mail: fborhani78@ut.ac.ir

M. Shafiepour Motlagh

e-mail: shafiepour@ut.ac.ir

A. H. Ehsani

e-mail: ehsani@ut.ac.ir

A. Stohl

Department of Meteorology and Geophysics, University

of Vienna, Vienna, Austria

e-mail: andreas.stohl@univie.ac.at

Y. Rashidi

Environmental Sciences Research Institute, Shahid

Beheshti University, Tehran, Iran

e-mail: y_rashidi@sbu.ac.ir
Finally, the monthly and annual levels of surface ozone and total column ozone were compared during the study period. The results show that the average ozone concentration in Tehran varied substantially between 2001 and 2008, and decreased after 2008 when stringent air quality control measures were implemented. The highest average concentration of ozone occurred in the southwest of Tehran. Although mobile and resident sources play an important role in the release of precursors, the results also indicate a significant effect of meteorological conditions on the changes in ozone concentration. This study is an effective step toward a better understanding of ozone changes in Tehran under the changing influence of precursors and meteorological conditions.

Keywords Tropospheric ozone $\cdot$ Short-lived climate pollutants - Meteorological condition - Air pollution · Climate change

\section{Introduction}

Air pollution is one of the main problems in industrial cities. Reducing the damage caused by air pollution requires careful evaluation of the pollutant concentrations and influencing parameters. In addition to pollutant emitters, meteorological parameters have a significant role in the amount of pollution and 
consequently the air quality of the urban environment (Javanbakht Amiri \& Khatami, 2012; Kayes et al., 2019). The city of Tehran, the capital of Iran, is facing an air pollution crisis in recent years due to population growth, increase in the number of vehicles, as well as the intense concentration and accumulation of industries (Sotoudeheian et al., 2014). Tehran is one of the most polluted cities in the world (EEA, 2018). Therefore, it is very important to study the air pollution trends in the city.

Tropospheric ozone $\left(\mathrm{O}_{3}\right)$ is a very strong oxidant that is an indicator of photochemical oxidants. Ozone is a summer pollutant and an important short-lived climate pollutant (Faridi et al., 2018; Liu et al., 2019). Tropospheric ozone plays an important role in atmospheric chemistry, air quality, and climate change and is harmful to human health and agricultural production (Agathokleous et al., 2020; Monks et al., 2015; WHO, 2003; Zeng et al., 2008). In recent years, high levels of ozone $\left(\mathrm{O}_{3}\right)$ and its effect on air quality have become a global challenge (Li et al., 2019; Paoletti et al., 2014). It has been suggested that for every $10 \mu \mathrm{g} / \mathrm{m}^{3}$ increase in ozone concentration, the daily human death rate increases by about $0.3 \%$ and the death rate of heart patients by about $0.4 \%$ (Colls \& Tiwary, 2009). Ozone has an associated radiative forcing of $0.35 \mathrm{~W} / \mathrm{m}^{2}$, but its maximum concentrations on the ground rarely last more than two to three hours (Cross \& Pierson, 2013). The half-life of tropospheric ozone at 20 degrees Celsius is about three days (Shindell et al., 2012). After carbon dioxide and methane, tropospheric ozone is the third leading cause of global warming (Fowler et al., 2008; Stevenson et al., 2006).

Tropospheric ozone is produced by chemical reactions between Volatile Organic Compounds (VOCs) and carbon monoxide ( $\mathrm{CO}$ ) and hydroxyl radicals $(\mathrm{OH})$ in the presence of nitrogen oxides (NOx) in the atmosphere. Therefore, nitrogen oxides $\left(\mathrm{NO}_{\mathrm{X}}\right)$ and VOCs (as well as CO) are precursors of tropospheric ozone (Crutzen, 1974; Retama et al., 2015). In other words, ozone is formed when pollutants react chemically in the presence of sunlight (Cao et al., 2019; Sudo \& Akimoto, 2007). In addition to natural sources, anthropogenic emissions of ozone precursors play a dominant role, especially in industrial cities such as Tehran. The main sources of carbon monoxide (CO), as one of the most important precursors of ozone, are the combustion of fossil fuels in vehicles, power plants and the burning of biomass (Brook et al., 2004; Godish et al., 2003).

Ozone concentrations are mostly controlled by the photochemical production from the precursors $\mathrm{NO}_{\mathrm{X}}$, VOCs and $\mathrm{CO}$, which in turn is influenced by the meteorological conditions (Calvert et al., 2015; IbarraBerastegi et al., 2008; Lu et al., 2019). Generally, photochemical production of ozone in the troposphere is the main factor in increasing the concentration of this pollutant in the troposphere (Archibald et al., 2020; Liu et al., 1987; Murao et al., 1990; Penkett et al., 1986; Seinfeld et al., 1986). The main reaction that produces ozone is:

$$
\begin{aligned}
& \mathrm{NO}_{2}+h v \rightarrow \mathrm{NO}+\mathrm{O} \\
& \mathrm{O}+\mathrm{O}_{2}+\mathrm{M} \rightarrow \mathrm{O}_{3}+\mathrm{M} \\
& \mathrm{O}_{3}+\mathrm{NO} \rightarrow \mathrm{NO}_{2}+\mathrm{O}_{2} \\
& \mathrm{NO}+\mathrm{RO}_{2} \rightarrow \mathrm{NO}_{2}+\mathrm{RO} \\
& \mathrm{RO}_{2}+\mathrm{O}_{2}+h v \rightarrow \mathrm{O}_{3}+\mathrm{RO}
\end{aligned}
$$

where $\mathrm{NO}, \mathrm{O}, \mathrm{O}_{2}, \mathrm{M}, \mathrm{NO}_{2}, \mathrm{RO}, \mathrm{RO}_{2}$ and hv are nitrogen monoxide, oxygen atoms, oxygen molecules, reaction energy adsorbent molecules, nitrogen dioxides, organic alkoxy radicals, organic peroxy radicals (where $\mathrm{R}$ is any organic group) and sunlight radiation, respectively.

Ozone molecules absorb UV rays. This adsorption process occurs when UV light breaks down an ozone molecule into an atom and an oxygen molecule. The oxygen atom then immediately combines with the next oxygen molecule to form another ozone molecule, and the energy is released into space as thermal (kinetic) energy. During these reactions, ROG (reactive organic gases) is an active organic gas that contains the active part $\mathrm{R}$ and hydrogen $\mathrm{H}$.

The available studies indicate that meteorological parameters such as wind direction, wind speed, temperature and relative humidity have a significant effect on changes in surface ozone concentration and its precursors in different months and seasons of the year (Elminir, 2005; Guicherit \& Van Dop, 1977; Kovac-Andric et al., 2009; Pawlak \& Jaroslawski, 2015; Szulejko et al., 2018). Duenas et al. (2002) investigated the effect of meteorological parameters on ozone concentration in the Malaga region. Climate change can lead to a significant increase in surface 
ozone, especially in polluted areas (Fiore et al., 2015; Kirtman et al., 2013). Mulumba et al. (2015) presented a model for evaluating surface ozone based on meteorological parameters such as temperature and relative humidity. Sousa et al. (2007) studied the effect of wind speed, relative humidity, temperature, nitrogen dioxide concentration and nitrogen oxide on ozone concentration. A study of tropospheric ozone precursors has shown serious pollution in Guangzhou, Shanghai and Lanzhou (Xue et al., 2014). $\mathrm{O}_{3}$ production in Shanghai and Guangzhou was limited by the availability of VOCs, whereas in Lanzhou it was limited by $\mathrm{NO}_{\mathrm{x}}$. Zhang et al. (2020) measured concentration of tropospheric ozone and its precursors as well as some meteorological parameters in the area near Shanghai, China, and reported one of the reasons for the high concentration of ozone $\left(\mathrm{O}_{3}\right)$ in this area as high air temperature.

Akbar and Sharee (2007) studied the changes in surface ozone in relation to meteorological conditions at the synoptic station of the Geophysical Institute in Tehran during 2002. Their results show average ozone levels of about $72 \mathrm{ppb}$ in the afternoon and about $26 \mathrm{ppb}$ in the morning. Also, the highest concentration of ozone (about $97 \mathrm{ppb}$ ) was recorded in spring and the lowest (about $14 \mathrm{ppb}$ ) in winter (Akbar \& Sharee, 2007). Ghiasodin and Sourati (2014) studied the concentration of ozone at one of the monitoring stations in Tehran and found an increase in the concentration of ozone due to sunlight and consequently an increase in photochemical activity. It has been suggested that surface stability increases the stability of photochemical processes in the atmosphere and thus increases the concentration of tropospheric ozone (Karimi, 2014).

Disentangling the relative roles of precursor emissions and meteorological conditions for tropospheric ozone formation in Tehran requires a long-term study. For this study, meteorological parameters (including temperature, T, wind speed, WS, dew point, DWP, relative humidity, $\mathrm{RH}$, and rainfall, $\mathrm{PP}$ ) and the concentrations of ozone precursors (NO, $\mathrm{NO}_{2}, \mathrm{NO}_{\mathrm{X}}$ and $\mathrm{CO}$ ) in Tehran were collected from 2001 to 2020 . The spatial distribution of 20-year average concentration of ozone precursors in air quality monitoring stations in Tehran was analyzed using ArcGIS program. Regression models of ozone concentration were developed based on ozone precursor concentrations and meteorological parameters, and resulting correlations were investigated. Finally, the monthly and annual average values of surface ozone and total ozone concentration were compared over the study period.

\section{Study area}

Tehran is one of the most populous cities in the world and the capital of Iran. The city with an area of 751 $\mathrm{km}^{2}$ is located at $35^{\circ} 68 / 92^{\prime \prime} N$ and $51^{\circ} 38 / 90 E$. The city of Tehran is limited to the north by the Alborz Mountains (at an altitude of about $1980 \mathrm{~m}$ above sea level) and to the south by the Central Desert (at an altitude of about $1200 \mathrm{~m}$ above sea level). The mean annual rainfall is $230 \mathrm{~mm}$, the maximum, mean and minimum temperatures are 43,17 and $-15{ }^{\circ} \mathrm{C}$, respectively, and the mean relative humidity is $40 \%$. $70 \%$ of wind speeds in Tehran are less than $3 \mathrm{~m}$ per second (Keyhani, 2010). Air pollution in Tehran is generally due to vehicles and industrial centers. Limited air exchange due to surrounding mountains, dry conditions and high emissions of ozone precursors create conditions that are very conducive to photochemical formation of ozone.

\section{Measurement data}

In the current research, air pollution data measured by Tehran Air Quality Control Company (AQCC) were used. $\mathrm{NO}, \mathrm{NO}_{2}, \mathrm{CO}$ and $\mathrm{O}_{3}$ concentration data from 2001 to 2020 were collected from 22 monitoring stations (i.e., Aqdasiyeh, Sharif University, Ray, District 21, Punak, Golbarg, Masoudieh, Tarbiat Modares University, District 10, Fath Sq., Setad Bohran, District 19, Shad Abad, Mahallati, Region 22, Sadr, Piroozi, District 2, District 11, Rose Park, District 4, Darous) of Tehran Air Quality Control Company (AQCC) and Environmental Protection Organization (DOE). Figure 1 shows the locations of these stations. They can be classified into two groups: Urban Stations and Traffic Stations (Table 1). WHO criteria were used to validate the data. Distorted information, including incorrect data (zero and negative data) and the data that were very inconsistent with other data due to local phenomena such as environmental issues (i.e., household waste, construction activities or fire and etc.) in the vicinity of the station, was removed from the database. The exact amount of ozone concentration in June 2006 was not 


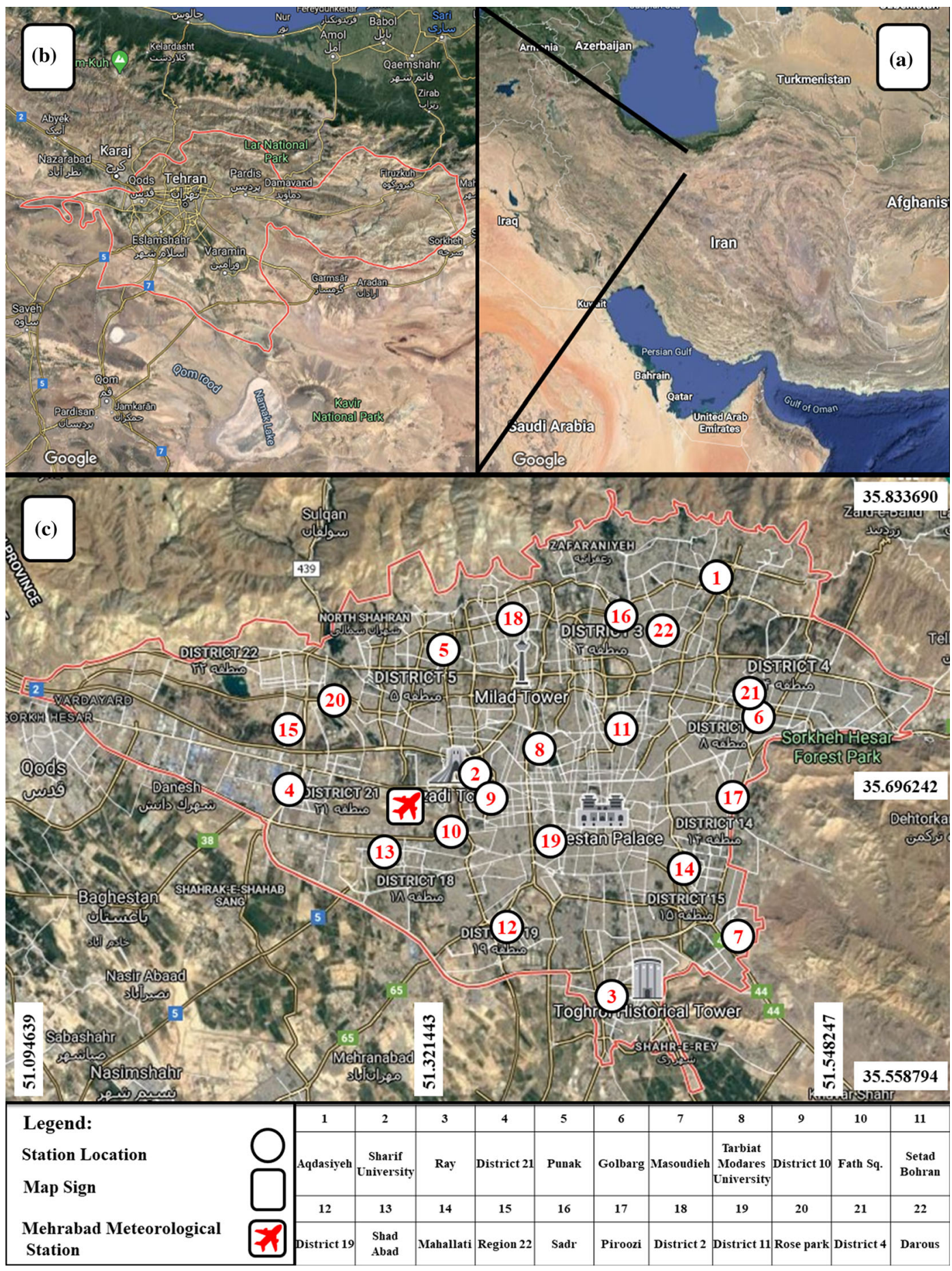

Fig. 1 Locations of the air quality monitoring stations and the meteorological station in Tehran city, a Iran, b Tehran Province, c) Tehran City

recorded, and this data gap was filled with the average value of May and July 2006. Only stations with more than $75 \%$ of hourly concentration data were used. The resulting data were converted to standard concentrations based on clean air standards provided by the US Environmental Protection Agency (USEPA, 1997). In 
Table 1 Average concentrations of $\mathrm{O}_{3}, \mathrm{NO}, \mathrm{NO}_{2}, \mathrm{NO}_{\mathrm{X}}$ and $\mathrm{CO}$ for the period of 2001 to 2020 in AQMS of Tehran

\begin{tabular}{|c|c|c|c|c|c|c|c|c|}
\hline NO & District & AQMS & $\begin{array}{l}\mathrm{O}_{3} \\
(\mathrm{ppb})\end{array}$ & $\begin{array}{l}\text { NO } \\
(\mathrm{ppb})\end{array}$ & $\begin{array}{l}\mathrm{NO}_{2} \\
(\mathrm{ppb})\end{array}$ & $\begin{array}{l}\mathrm{NO}_{\mathrm{x}} \\
(\mathrm{ppb})\end{array}$ & $\begin{array}{l}\mathrm{CO} \\
(\mathrm{ppm})\end{array}$ & $\begin{array}{l}\text { Station } \\
\text { type }\end{array}$ \\
\hline 1 & 1 & Aqdasiyeh & 29.00 & 56.00 & 57.50 & 111.00 & 3.00 & TS \\
\hline 2 & 2 & Sharif University & 21.00 & 48.00 & 67.00 & 114.00 & 2.00 & US \\
\hline 3 & 20 & Ray & 24.00 & 83.00 & 55.00 & 135.00 & 3.00 & TS \\
\hline 4 & 21 & District 21 & 21.00 & 69.00 & 49.00 & 117.00 & 2.50 & $\mathrm{TS}$ \\
\hline 5 & 5 & Punak & 35.00 & 50.00 & 58.00 & 107.00 & 4.00 & $\mathrm{TS}$ \\
\hline 6 & 8 & Golbarg & 25.00 & 34.00 & 43.00 & 76.00 & 3.00 & US \\
\hline 7 & 15 & Masoudieh & 37.00 & 30.00 & 43.50 & 72.00 & 3.60 & $\mathrm{TS}$ \\
\hline 8 & 6 & Tarbiat Modares University & 22.00 & 60.00 & 43.00 & 101.00 & 2.00 & US \\
\hline 9 & 10 & District 10 & 17.00 & 179.00 & 113.00 & 290.00 & 3.10 & TS \\
\hline 10 & 9 & Fath $\mathrm{Sq}$ & 23.00 & 93.00 & 45.00 & 136.00 & 2.00 & $\mathrm{TS}$ \\
\hline 11 & 7 & Setad Bohran & 24.00 & 70.00 & 48.00 & 117.00 & 4.25 & US \\
\hline 12 & 19 & District 19 & 22.00 & 66.00 & 47.00 & 110.00 & 3.20 & US \\
\hline 13 & 18 & Shad Abad & 25.00 & 44.00 & 35.00 & 78.00 & 3.60 & $\mathrm{TS}$ \\
\hline 14 & 14 & Mahallati & 19.00 & 57.00 & 43.00 & 99.00 & 2.00 & US \\
\hline 15 & 22 & Region 22 & 27.00 & 41.00 & 44.00 & 84.00 & 1.50 & US \\
\hline 16 & 3 & Sadr & 23.00 & 112.00 & 70.50 & 178.00 & 5.10 & TS \\
\hline 17 & 13 & Piroozi & 23.50 & 50.00 & 42.00 & 91.00 & 2.70 & US \\
\hline 18 & 2 & District 2 & 24.00 & 57.00 & 74.50 & 130.00 & 3.00 & US \\
\hline 19 & 11 & District 11 & 18.00 & 66.00 & 59.50 & 123.00 & 3.40 & $\mathrm{TS}$ \\
\hline 20 & 22 & Rose park & 31.00 & 32.00 & 44.00 & 73.00 & 2.50 & $\mathrm{TS}$ \\
\hline 21 & 4 & District 4 & 17.00 & 114.00 & 85.00 & 197.50 & 3.50 & $\mathrm{TS}$ \\
\hline 22 & 3 & Darous & 25.00 & 54.00 & 45.00 & 97.00 & 3.80 & $\mathrm{TS}$ \\
\hline
\end{tabular}

AQMS: air quality monitoring stations, $T S$ : traffic station, $U S$ : urban station

this standard, a maximum concentration of eight hours was used for carbon monoxide, a maximum concentration of one hour and eight hours for ozone and a maximum concentration of one hour for nitrogen dioxide.

At the stations of the air quality control company, ozone was measured with an analyzer $\mathrm{O}_{3} 42$ model (Environnement S.A., Poissy, France). This analyzer is a continuous ozone analyzer and measures ozone concentration with advanced UV (ultraviolet) technologies. The Beer-Lambert law was used to determine the $\mathrm{O}_{3}$ concentration:

$I=I_{0} e^{-\mu x}$

$\mu=\alpha \times C$

where $\mathrm{I}$ and $\mathrm{I}_{0}$ are the transfer and production flux densities, $\mu$ is substrate analysis coefficient, $\mathrm{X}$ is the path lengths through the substrate, $\alpha$ is the adsorption cross section and $\mathrm{C}$ is the ozone concentration.
The chemiluminescence technique was used to measure the concentrations of nitrogen oxides (instruments APNA-370 of Horiba, Japan; AC $32 \mathrm{M}$ of Environment SA, France; and EC 9841 of Ecotech, Australia). CO concentrations were measured using non-dispersive infrared (NDIR) analyzers (model Teledyne API model 300E, San Diego, CA).

In air quality control stations in Tehran, inorganic gaseous pollutants $\mathrm{NO}, \mathrm{NO}_{2}, \mathrm{CO}$ and $\mathrm{O}_{3}$ are analyzed according to international air quality standards in Europe 2008/50/EC and revised standard 2015/1480/ EC. Periodic services and multiple calibrations of the analyzers are performed based on a specific schedule and at specified intervals according to international standards in the sampling process so that the quality of the results is in accordance with the Quality Assurance program. Satellite data from the Total Ozone Mapping Spectrometer were measured by EP/TOMS (built by TRW Space \& Electronics Group, Redondo Beach, CA) from 2001 to 2004 and the Ozone Monitoring 
Fig. 2 Distribution of annual average concentration in air quality monitoring stations in Tehran from 2001 to 2020 , a $\mathrm{NO}, \mathbf{b ~} \mathrm{NO}_{2}, \mathbf{c} \mathrm{NO}_{\mathrm{X}}, \mathbf{d ~ C O}$ e $\mathrm{O}_{3}$
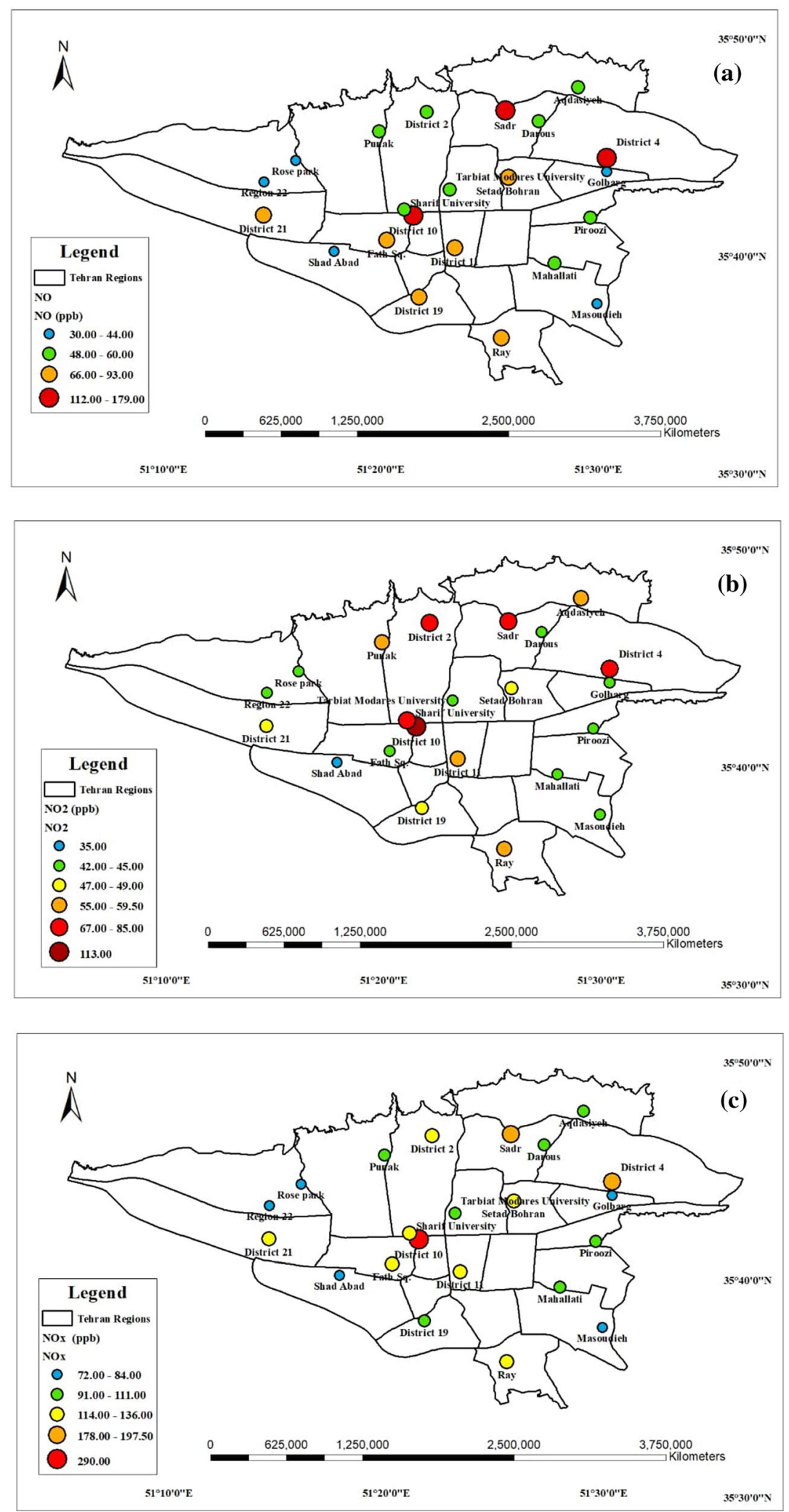
Fig. 2 continued

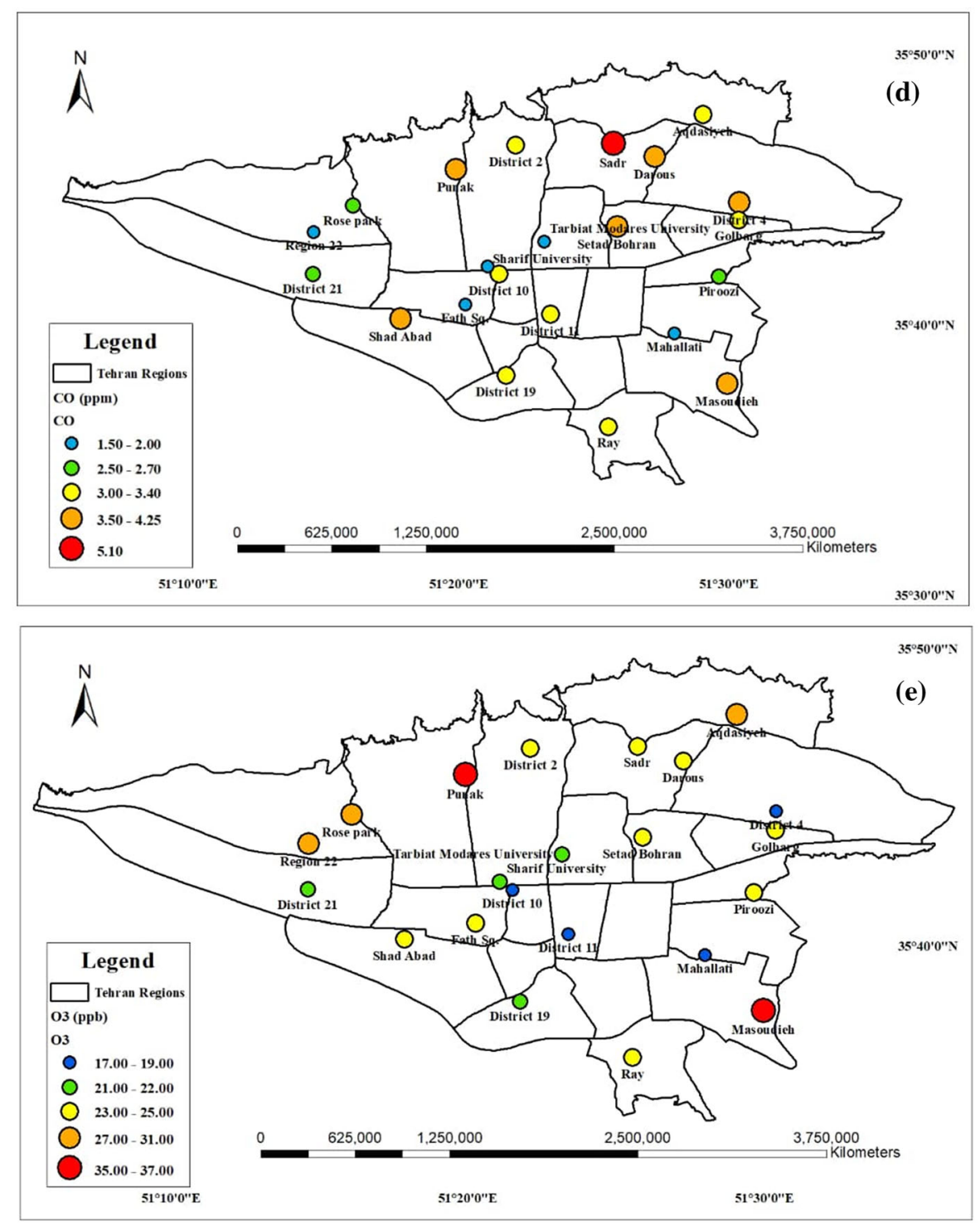

Interferometer (OMI) from 2005 to 2020 . OMI is a sensor contribution of NIVR (Netherlands Institute for Air and Space Development) of Delft in collaboration with FMI (Finnish Meteorological Institute), Helsinki, Finland. The instrument was built by Dutch Space in co-operation with Netherlands Organisation for Applied Scientific Research Science and Industry and Netherlands Institute for Space Research (McPeters et al., 1998; Giovanni, 2020). Meteorological data (including air temperature, wind speed, relative humidity, dew point and rainfall) data are recorded by Mehrabad Meteorological Station. Mehrabad Meteorological Station is located at $35^{\circ} 68^{\prime} \mathrm{N}$ and $51^{\circ} 35^{\prime} E$ (see Fig. 1), in the vicinity of Mehrabad Airport, inside the city.

\section{Results and discussion}

Monthly, Seasonal and annual trends of ozone and its precursors

Table 1 presents the average annual concentration of ozone and its precursors $\left(\mathrm{NO}, \mathrm{NO}_{2}, \mathrm{NO}_{\mathrm{X}}\right.$ and $\left.\mathrm{CO}\right)$ at 22 air quality monitoring stations in Tehran. Figure 2 shows the spatial distribution of the 20 year average 
Table 2 Annual average of tropospheric ozone, precursors and meteorological parameters recorded from 2001 to 2020 in Tehran

\begin{tabular}{llllllllllll}
\hline Month & $\mathrm{O}_{3}(\mathrm{ppb})$ & $\begin{array}{l}\mathrm{O}_{3} \\
(\mathrm{DU})\end{array}$ & $\mathrm{NO}(\mathrm{ppb})$ & $\mathrm{NO}_{2}(\mathrm{ppb})$ & $\mathrm{NO}_{\mathrm{x}}(\mathrm{ppb})$ & $\mathrm{CO}(\mathrm{ppm})$ & $\begin{array}{l}\mathrm{T} \\
\left({ }^{\circ} \mathrm{C}\right)\end{array}$ & WS $(\mathrm{Knot})$ & $\begin{array}{l}\mathrm{RH} \\
(\%)\end{array}$ & $\begin{array}{l}\mathrm{DWP} \\
\left({ }^{\circ} \mathrm{C}\right)\end{array}$ & $\begin{array}{l}\mathrm{PP} \\
(\mathrm{mm})\end{array}$ \\
\hline Jan & 15.89 & 296.90 & 88.34 & 62.81 & 149.72 & 3.49 & 5.04 & 4.79 & 55.61 & -4.00 & 37.80 \\
Feb & 19.90 & 314.66 & 73.74 & 59.94 & 132.12 & 3.32 & 7.31 & 6.10 & 49.49 & -3.64 & 34.73 \\
Mar & 25.93 & 315.92 & 57.84 & 54.86 & 109.75 & 2.97 & 12.85 & 7.03 & 40.33 & -2.18 & 32.93 \\
Apr & 25.21 & 314.70 & 50.86 & 52.40 & 99.57 & 3.01 & 17.65 & 7.06 & 38.14 & 1.37 & 42.12 \\
May & 29.33 & 302.05 & 50.44 & 54.20 & 100.23 & 2.67 & 23.64 & 7.73 & 28.84 & 2.59 & 12.23 \\
Jun & 34.88 & 286.09 & 44.04 & 51.98 & 94.02 & 2.81 & 29.30 & 6.90 & 21.83 & 3.43 & 10.39 \\
Jul & 35.07 & 279.90 & 49.19 & 52.03 & 98.42 & 3.05 & 31.79 & 6.39 & 22.82 & 6.16 & 9.70 \\
Aug & 32.23 & 278.14 & 52.76 & 53.75 & 106.01 & 3.08 & 30.63 & 5.67 & 23.36 & 5.76 & 1.54 \\
Sep & 25.55 & 272.16 & 63.13 & 54.13 & 116.59 & 3.19 & 26.82 & 5.42 & 25.34 & 3.74 & 1.24 \\
Oct & 20.53 & 265.03 & 75.88 & 52.98 & 127.33 & 3.39 & 20.13 & 5.15 & 34.74 & 2.41 & 15.34 \\
Nov & 14.88 & 269.74 & 88.06 & 58.39 & 145.53 & 3.72 & 11.59 & 5.43 & 49.32 & 0.17 & 32.38 \\
Dec & 12.43 & 279.05 & 98.84 & 61.72 & 158.96 & 3.98 & 6.50 & 4.20 & 56.63 & -2.24 & 31.02 \\
\hline
\end{tabular}

concentrations of the pollutants. The monthly average of tropospheric ozone, precursors and meteorological parameters recorded from 2001 to 2020 over all stations in Tehran are presented in appendix, Table A. In the period of 2001 to 2020 , the minimum and maximum average annual concentrations of $\mathrm{NO}_{2}$ were $10.71 \mathrm{ppb}$ in 2002 and $35.88 \mathrm{ppb}$ in 2013, respectively (Table A). The maximum annual average concentrations of $\mathrm{NO}, \mathrm{NO}_{2}$ and $\mathrm{NO}_{\mathrm{X}}$ were $179 \mathrm{ppb}, 113 \mathrm{ppb}$ and $290 \mathrm{ppb}$, respectively, at the District 10 station (Figs. 2a, b, c and Table 1). These values are higher than the EPA limit (i.e., $100 \mathrm{ppb}$ ). The minimum average concentrations of $\mathrm{NO}$ and $\mathrm{NO}_{\mathrm{X}}$ were recorded in Masoudieh station, equal to $30 \mathrm{ppb}$ and $72 \mathrm{ppb}$, respectively (Table 1). The minimum average concentration of $\mathrm{NO}_{2}$ was recorded in Shadabad station, equal to $35 \mathrm{ppb}$ (Table 1). Table 2 presents the average monthly values of ozone concentration, precursors and meteorological parameters in the period of 2001 to 2020 in Tehran. As presented in the table, the maximum nitrogen oxides concentrations occurred in the cold season. The maximum monthly average values of $\mathrm{NO}$ and $\mathrm{NO}_{\mathrm{X}}$ were recorded in December at $98.84 \mathrm{ppb}$ and $158.96 \mathrm{ppb}$, respectively (Table 2). The maximum average annual concentrations of NO and $\mathrm{NO}_{\mathrm{X}}$ were $102 \mathrm{ppb}$ in 2010 and 177.83 ppb in 2002, respectively. The maximum average concentration of $\mathrm{NO}_{2}$ was recorded in December and January equal to $61.72 \mathrm{ppb}$ and $62.81 \mathrm{ppb}$, respectively. There were a substantial decrease in $\mathrm{NO}_{2}$ concentrations from 2002 to 2006 , an increase in 2007 and only small changes thereafter.

Investigation of carbon monoxide (CO) changes shows that the maximum and minimum average annual concentrations were $5.92 \mathrm{ppm}$ in 2005 and $1.84 \mathrm{ppm}$ in 2020, respectively (Table A). The maximum and minimum average daily concentrations during recent 20 years have been recorded at Sadr station, a traffic station, and District 22 station, an urban station, respectively (Table 1 and Fig. 2d). An examination of the trend of changes in carbon monoxide concentrations in Tehran indicates that the CO concentration was decreasing from 2001 to 2002, increasing from 2002 to 2005 , followed by a substantial decrease to the minimum value in 2020. It should be noted that the $\mathrm{CO}$ concentration recorded in these years was less than the allowable EPA value (i.e., $9.4 \mathrm{ppm})$. The main reason for the low 2020 value was the spread of the Corona virus and the related restrictions that caused a reduction in industrial and traffic activities in Tehran (Borhani et al., 2021). Worden et al. (2013) also investigated pollutants in the eastern USA and Europe and parts of Asia, showing that the carbon monoxide concentration decreased from 2000 to 2011 . The relatively declining trend of carbon monoxide concentrations in Tehran from 2001 to 2020 shows that the implementation of policies such as gasification of cars, use of traffic plans, technical inspection of cars, replacement of worn-out cars and Metro development has played a vital role in reducing CO concentrations. 

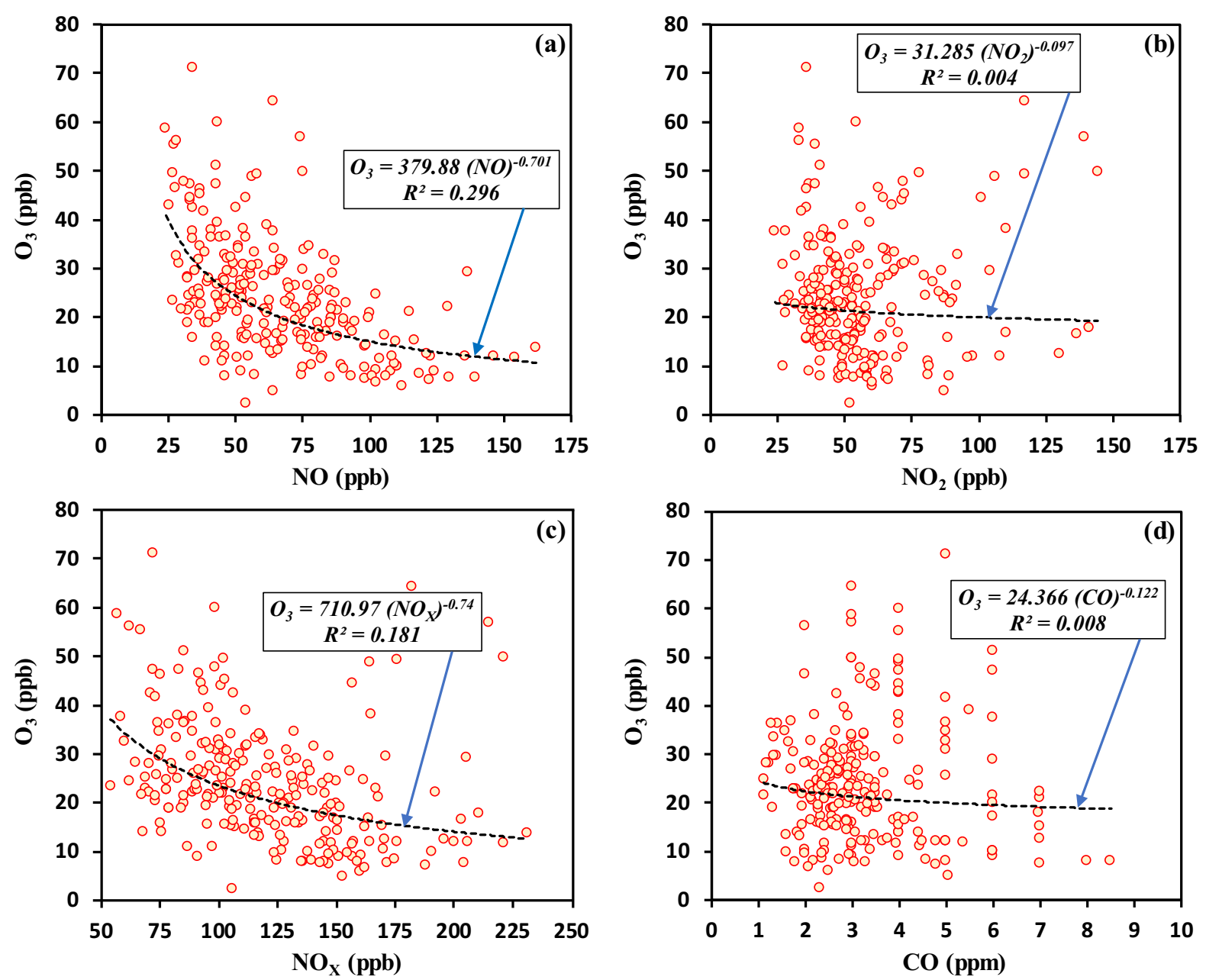

Fig. 3 Variation of $\mathrm{O}_{3}$ against, $\mathbf{a} \mathrm{NO}, \mathbf{b} \mathrm{NO}_{2}, \mathbf{c} \mathrm{NO}_{\mathbf{X}}, \mathbf{d ~ C O}$; the best fitted curve to data and related equation are also superimposed on the plot

Investigating ozone average concentration over all stations shows that the minimum and maximum annual concentrations were $13.88 \mathrm{ppb}$ in 2003 and 40 ppb in 2004, respectively (Table A). The maximum average ozone concentration was recorded at Masoudieh station (Table 1 and Fig. 2e). The average ozone concentration increased sharply from 2001 to 2002 and decreased from 2003 to 2007.

$\mathrm{NO}_{2}, \mathrm{NO}_{\mathrm{x}}$ and $\mathrm{CO}$ show similar seasonal variability, with high levels recorded in late autumn and winter and low levels recorded in spring and summer (Table 2). This is different from the seasonality of $\mathrm{O}_{3}$ (Figs. 3a, b, c and 4d), which increases from January and reaches its maximum value in June, the driest month. This finding is in agreement with the results of previous studies (Jo \& Park, 2005; Raddatz \&
Cummine, 2001; Saito et al., 2002). Then, with increasing relative humidity and rainfall, the surface ozone concentration decreases until December. The low concentration of surface ozone is significant in cold seasons (USEPA, 2011).

Seasonal and monthly variations in total column ozone

Table 2 presents the average seasonal variation in total column ozone. The maximum ozone concentration in March and April is 315.92 DU and 314.70 DU, respectively, and the minimum in October and November is 265.03 DU and 269.74 DU units, respectively (Fig. 5). Figure 6 shows the changes in total ozone and surface ozone from 2001 to 2020 using 
Table 3 Spearman's rank correlations between tropospheric ozone, precursors and meteorological parameters data from 2001 to 2020 in Tehran

\begin{tabular}{|c|c|c|c|c|c|c|c|c|c|c|}
\hline Parameters & $\mathrm{O}_{3}(\mathrm{ppb})$ & NO (ppb) & $\begin{array}{l}\mathrm{NO}_{2} \\
(\mathrm{ppb})\end{array}$ & $\begin{array}{l}\mathrm{NO}_{\mathrm{X}} \\
(\mathrm{ppb})\end{array}$ & $\begin{array}{l}\mathrm{CO} \\
(\mathrm{ppm})\end{array}$ & $\mathrm{T}\left({ }^{\circ} \mathrm{C}\right)$ & $\begin{array}{l}\text { WS } \\
\text { (Knot) }\end{array}$ & RH (\%) & $\begin{array}{l}\text { DWP } \\
\left({ }^{\circ} \mathrm{C}\right)\end{array}$ & $\begin{array}{l}\mathrm{PP} \\
(\mathrm{mm})\end{array}$ \\
\hline $\mathrm{O}_{3}(\mathrm{ppb})$ & 1 & & & & & & & & & \\
\hline NO (ppb) & $-0.937 *$ & 1 & & & & & & & & \\
\hline $\mathrm{NO}_{2}(\mathrm{ppb})$ & $-0.810^{*}$ & 0.859 & 1 & & & & & & & \\
\hline $\mathrm{NO}_{\mathrm{X}}(\mathrm{ppb})$ & $-0.925^{*}$ & 0.995 & 0.897 & 1 & & & & & & \\
\hline $\mathrm{CO}(\mathrm{ppm})$ & $-0.853 *$ & 0.945 & 0.742 & 0.935 & 1 & & & & & \\
\hline $\mathrm{T}\left({ }^{\circ} \mathrm{C}\right)$ & 0.872 & $-0.795 *$ & $-0.862 *$ & $-0.806^{*}$ & $-0.658 *$ & 1 & & & & \\
\hline WS (Knot) & 0.671 & $-0.831 *$ & $-0.626^{*}$ & $-0.832 *$ & $-0.890 *$ & 0.414 & 1 & & & \\
\hline RH (\%) & $-0.908 *$ & 0.862 & 0.896 & 0.871 & 0.761 & $-0.982 *$ & $-0.519 *$ & 1 & & \\
\hline DWP $\left({ }^{\circ} \mathrm{C}\right)$ & 0.742 & $-0.669 *$ & $-0.822 *$ & $-0.693 *$ & $-0.497 *$ & 0.966 & 0.284 & $-0.910 *$ & 1 & \\
\hline $\mathrm{PP}(\mathrm{mm})$ & $-0.644 *$ & 0.489 & 0.579 & 0.490 & 0.411 & $-0.864 *$ & $-0.087 *$ & 0.840 & $-0.832 *$ & 1 \\
\hline
\end{tabular}

$* P<0.05$

satellite data and terrestrial monitoring. As shown in this figure, the concentration of ozone at the surface has been increasing and the average ozone in the vertical column of the atmosphere and ground monitoring from 271.52 DU and $15.91 \mathrm{ppb}$ in 2001 to $295.07 \mathrm{DU}$ and $20.87 \mathrm{ppb}$ in 2020, respectively. From 2001 to 2020 , total columnar ozone increased by 23.55 DU and surface ozone by $4.96 \mathrm{ppb}$.

High temperatures and low relative humidity are conducive to the formation of tropospheric ozone (Table 3). Surface ozone is part of the total atmosphere ozone. Total atmospheric ozone is the sum of tropospheric and stratospheric ozone in a vertical column with a cross-sectional area of one square centimeter from the atmosphere boundary to the ground (Danielsen, 1968; Fishman et al., 2003; Junge, 1962). Investigation of the trend of annual changes in total ozone indicates that the greatest change occurs in winter and spring. Relative decrease in average surface ozone concentration in winter $(20.57 \mathrm{ppb})$ despite high levels of total ozone (309.16 DU) can be due to increased rainfall $(35.15 \mathrm{~mm})$ and decreased temperature $\left(8.40{ }^{\circ} \mathrm{C}\right)$ and subsequently attenuation of overnight temperature inversion and reduction in high concentrations of pollutants (Fig. 5).

Statistical analysis

Table 3 presents the average Pearson correlation coefficient (R) (Ozbay, 2012) between ozone, ozone precursors and meteorological parameters. The value of $P<0.05$ was considered statistically significant. There is a negative correlation between ozone and NO, $\mathrm{NO}_{2}, \mathrm{NO}_{\mathrm{x}}$ and $\mathrm{CO}$. Nitrogen monoxide (NO) has the highest negative correlation (Fig. 3a) because it leads to titration of ozone; with the decrease in NOxtitration effects, the ozone concentration increases significantly (Li et al., 2013; Sillman, 1999). The temperature (T) and dew point (DWP) have the highest positive correlation with surface ozone (Fig. 4a and d). This can be attributed to the predominant role of temperature in photochemical reactions in ozone formation (Chelani, 2009; Shan, 2009). In addition, on an annual time scale, a significant correlation was observed between temperature and dew point $(\mathrm{r}=0.966)$. Relative humidity and rainfall rate are negatively correlated with surface ozone (Fig. 4c and e). Han et al. (2020), examining the effects of meteorological parameters on ozone concentration in East China reported that higher humidity is associated with cloud formation and slows ozone production because of a reduction in solar insolation. Camalier et al. (2007) show that high humidity may be partially associated with atmospheric instability and cause surface ozone dispersion.

Ozone concentrations increased with increasing wind speed $(P>0.05)$ (Fig. $4 b)$. Wind can transport air that contains ozone or other pollutants from their sources. Sometimes the combined effect of two or more parallel or inverted parameters is more pronounced in the amount of surface ozone concentration. The combined effect of rainfall and relative humidity 

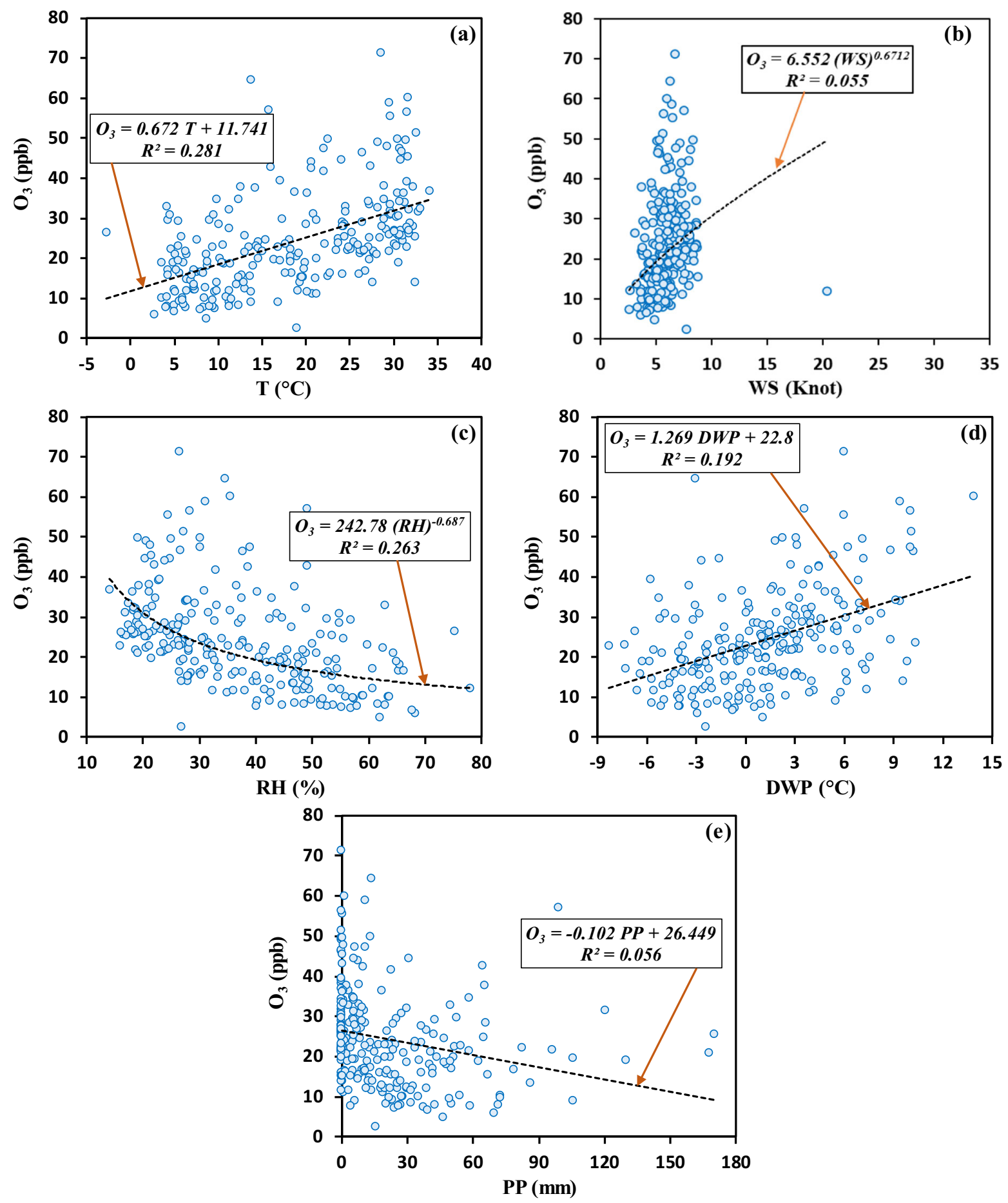

Fig. 4 Variation of $\mathrm{O}_{3}$ against, a T, b WS, $\mathbf{c}$ RH, d DWP, e PP; the best fitted curve to data and related equation are also superimposed on the plot 
with the decreasing role of surface ozone overcomes the increasing role of air temperature.

\section{Conclusions}

The changes in ozone concentration due to changes in its precursors $\left(\mathrm{NO}, \mathrm{NO}_{2}, \mathrm{NO}_{\mathrm{X}}\right.$ and $\left.\mathrm{CO}\right)$ as well as meteorological conditions (temperature, humidity, wind speed, dew point and rainfall) in the last two decades in Tehran were investigated. Ozone and precursor data were collected from 22 air quality control stations in Tehran, including urban and traffic stations. Meteorological data were also gathered. The spatial distribution of the average concentration of ozone and its precursors was determined according to the geographical location of the stations. Investigating the changes in pollutants from 2001 to 2020 in the city of Tehran indicated that the concentrations in traffic stations are higher than urban stations. According to distribution of annual average concentration in air quality monitoring stations, the highest average concentration of ozone is recorded in the southwest of Tehran. The concentration of ozone in the outskirts of Tehran is higher than its central region. The study of changes in ozone concentration in the last two decades in Tehran shows a $25 \%$ decrease in the second decade (2011-2020) compared to the first decade (2001-2010). Observance of environmental standards in vehicles production, traffic control through new
Fig. 5 Comparison of monthly average of tropospheric ozone and Total ozone from 2001 to 2020

Fig. 6 Comparison of annual average of tropospheric ozone and Total ozone from 2001 to 2020
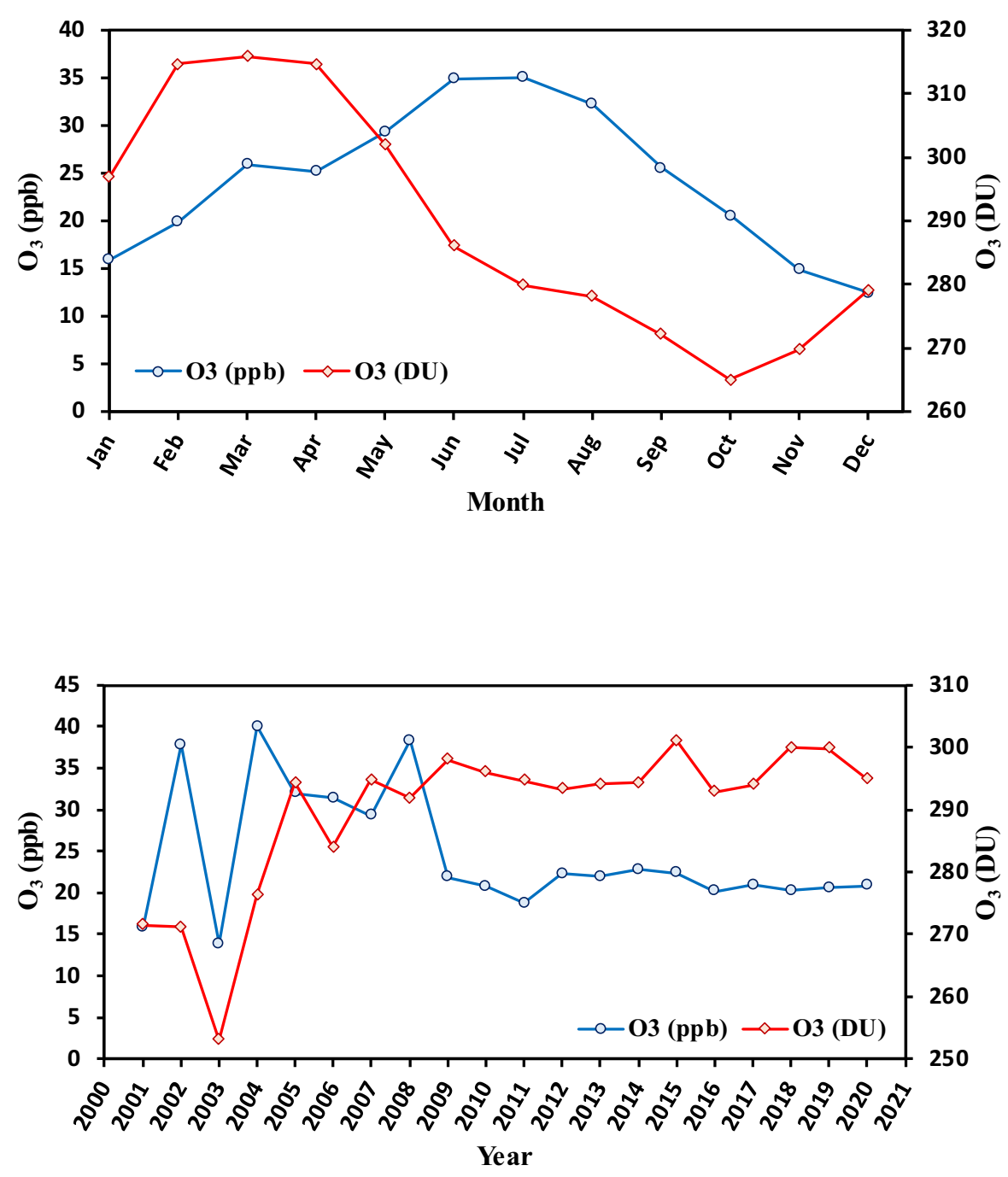
Table 4 Monthly average of tropospheric ozone, precursors and meteorological parameters recorded from 2001 to 2020

\begin{tabular}{|c|c|c|c|c|c|c|c|c|c|c|c|c|}
\hline \multirow[t]{3}{*}{ Year } & \multirow[t]{3}{*}{ Month } & \multicolumn{11}{|c|}{ Parameters } \\
\hline & & \multicolumn{2}{|l|}{ Ozone } & \multicolumn{4}{|c|}{ Precursors Parameters } & \multicolumn{5}{|c|}{ Meteorological Parameters } \\
\hline & & $\begin{array}{l}\mathrm{O}_{3} \\
(\mathrm{ppb})\end{array}$ & $\begin{array}{l}\mathrm{O}_{3} \\
(\mathrm{DU})\end{array}$ & $\begin{array}{l}\text { NO } \\
(p p b)\end{array}$ & $\begin{array}{l}\mathrm{NO}_{2} \\
(\mathrm{ppb})\end{array}$ & $\begin{array}{l}\mathrm{NO}_{\mathrm{X}} \\
(\mathrm{ppb})\end{array}$ & $\begin{array}{l}\mathrm{CO} \\
(\mathrm{ppm})\end{array}$ & $\mathrm{T}\left({ }^{\circ} \mathrm{C}\right)$ & $\begin{array}{l}\text { WS } \\
\text { (Knot) }\end{array}$ & $\begin{array}{l}\mathrm{RH} \\
(\%)\end{array}$ & $\begin{array}{l}\text { DWP } \\
\left({ }^{\circ} \mathrm{C}\right)\end{array}$ & $\begin{array}{l}\mathrm{PP} \\
(\mathrm{mm})\end{array}$ \\
\hline \multirow[t]{12}{*}{2001} & Jan & 12.17 & 251.30 & 46.04 & 97.42 & 144.77 & 4.77 & 4.93 & 2.66 & 78.10 & 1.12 & 29.96 \\
\hline & Feb & 16.53 & 276.00 & 65.32 & 136.53 & 203.11 & 3.89 & 7.59 & 5.67 & 65.29 & 1.06 & 1.52 \\
\hline & Mar & 18.00 & 279.30 & 67.61 & 140.89 & 210.67 & 6.96 & 13.97 & 4.54 & 65.60 & 7.13 & 40.12 \\
\hline & Apr & 11.14 & 301.40 & 38.65 & 80.95 & 97.45 & 4.43 & 20.80 & 7.34 & 42.61 & 5.81 & 0.76 \\
\hline & May & 15.96 & 306.70 & 43.33 & 88.40 & 134.44 & 2.24 & 24.16 & 7.91 & 28.50 & 3.12 & 17.26 \\
\hline & Jun & 27.18 & 301.80 & 39.73 & 83.00 & 123.95 & 3.04 & 29.11 & 7.27 & 26.17 & 5.59 & 8.89 \\
\hline & Jul & 23.67 & 291.30 & 43.67 & 90.20 & 136.40 & 4.40 & 30.06 & 7.34 & 31.60 & 10.33 & 0.51 \\
\hline & Aug & 24.45 & 271.30 & 42.77 & 87.00 & 131.32 & 4.22 & 31.07 & 6.37 & 27.37 & 8.83 & 2.54 \\
\hline & Sep & 16.86 & 263.40 & 52.27 & 110.07 & 163.72 & 4.31 & 26.73 & 6.55 & 30.94 & 7.35 & 9.65 \\
\hline & Oct & 11.73 & 242.00 & 50.65 & 95.88 & 147.73 & 5.35 & 20.19 & 6.39 & 37.98 & 4.19 & 13.70 \\
\hline & Nov & 8.37 & 235.70 & 57.00 & 81.05 & 139.38 & 4.57 & 12.30 & 6.35 & 48.53 & 0.94 & 50.04 \\
\hline & Dec & 4.93 & 238.00 & 64.23 & 86.93 & 152.46 & 5.03 & 8.66 & 4.83 & 62.00 & 1.09 & 46.48 \\
\hline \multirow[t]{12}{*}{2002} & Jan & 3.29 & 256.10 & 136.50 & 68.00 & 205.50 & 3.50 & 5.42 & 5.47 & 56.78 & -3.17 & 42.68 \\
\hline & Feb & 5.29 & 278.21 & 65.00 & 104.00 & 171.00 & 3.00 & 8.99 & 6.75 & 42.40 & -4.26 & 5.08 \\
\hline & Mar & 4.64 & 281.76 & 64.00 & 117.00 & 182.00 & 3.00 & 13.75 & 6.24 & 34.58 & -3.03 & 13.71 \\
\hline & Apr & 1.57 & 300.67 & 74.00 & 139.00 & 215.00 & 3.00 & 15.73 & 7.46 & 49.03 & 3.61 & 98.79 \\
\hline & May & 8.49 & 305.22 & 75.00 & 144.00 & 221.00 & 3.00 & 22.47 & 8.28 & 30.08 & 2.26 & 13.46 \\
\hline & Jun & 49.00 & 300.75 & 56.00 & 106.00 & 164.00 & 4.00 & 28.21 & 7.15 & 20.51 & 1.80 & 0.00 \\
\hline & Jul & 5.44 & 289.51 & 54.00 & 101.00 & 157.00 & 4.00 & 30.87 & 6.14 & 24.88 & 7.18 & 30.98 \\
\hline & Aug & 5.49 & 266.16 & 58.00 & 117.00 & 176.00 & 4.00 & 31.41 & 5.05 & 24.95 & 7.16 & 0.00 \\
\hline & Sep & 1.38 & 261.38 & 53.00 & 110.00 & 165.00 & 4.00 & 28.92 & 3.69 & 21.07 & 3.53 & 0.00 \\
\hline & Oct & 9.21 & 241.40 & 77.50 & 67.50 & 145.50 & 3.50 & 23.44 & 3.67 & 31.41 & 4.69 & 1.78 \\
\hline & Nov & 5.12 & 234.76 & 64.00 & 130.00 & 196.00 & 7.00 & 13.06 & 3.59 & 48.82 & 1.43 & 29.72 \\
\hline & Dec & 8.00 & 237.84 & 46.00 & 89.00 & 136.00 & 5.00 & 4.13 & 4.20 & 63.00 & -3.03 & 71.39 \\
\hline \multirow[t]{12}{*}{2003} & Jan & 12.00 & 254.25 & 55.00 & 108.00 & 164.00 & 5.00 & 6.44 & 4.17 & 55.10 & -2.62 & 25.66 \\
\hline & Feb & 17.00 & 277.94 & 73.00 & 70.00 & 149.00 & 4.00 & 7.23 & 5.69 & 54.39 & -2.23 & 41.65 \\
\hline & Mar & 20.00 & 296.00 & 43.00 & 40.00 & 85.00 & 3.00 & 10.18 & 4.74 & 47.46 & -1.55 & 43.44 \\
\hline & Apr & 9.00 & 277.29 & 52.00 & 37.00 & 91.00 & 4.00 & 16.89 & 6.07 & 51.53 & 5.50 & 105.41 \\
\hline & May & 11.00 & 282.16 & 45.00 & 41.00 & 87.00 & 3.00 & 21.26 & 6.40 & 34.85 & 3.88 & 18.78 \\
\hline & Jun & 14.00 & 253.66 & 43.00 & 43.00 & 76.00 & 4.00 & 27.63 & 6.23 & 27.85 & 6.16 & 0.25 \\
\hline & Jul & 14.00 & 229.14 & 46.00 & 44.00 & 68.00 & 4.00 & 32.43 & 6.04 & 26.75 & 9.61 & 0.00 \\
\hline & Aug & 19.00 & 238.63 & 32.00 & 47.00 & 79.00 & 3.50 & 30.57 & 4.54 & 29.20 & 9.87 & 0.00 \\
\hline & Sep & 16.00 & 228.06 & 34.00 & 40.00 & 75.00 & 3.00 & 26.07 & 3.88 & 30.15 & 6.13 & 0.00 \\
\hline & Oct & 15.50 & 216.04 & 58.00 & 36.00 & 95.00 & 4.00 & 22.53 & 4.44 & 30.26 & 3.00 & 7.88 \\
\hline & Nov & 9.00 & 227.86 & 108.00 & 48.00 & 157.00 & 6.00 & 11.31 & 4.58 & 42.51 & -1.69 & 6.09 \\
\hline & Dec & 10.00 & 256.12 & 110.00 & 27.00 & 138.00 & 6.00 & 5.90 & 3.73 & 63.49 & -1.04 & 34.80 \\
\hline
\end{tabular}


Table 4 continued

\begin{tabular}{|c|c|c|c|c|c|c|c|c|c|c|c|c|}
\hline \multirow[t]{3}{*}{ Year } & \multirow[t]{3}{*}{ Month } & \multicolumn{11}{|c|}{ Parameters } \\
\hline & & \multicolumn{2}{|l|}{ Ozone } & \multicolumn{4}{|c|}{ Precursors Parameters } & \multicolumn{5}{|c|}{ Meteorological Parameters } \\
\hline & & $\begin{array}{l}\mathrm{O}_{3} \\
(\mathrm{ppb})\end{array}$ & $\begin{array}{l}\mathrm{O}_{3} \\
(\mathrm{DU})\end{array}$ & $\begin{array}{l}\text { NO } \\
(p p b)\end{array}$ & $\begin{array}{l}\mathrm{NO}_{2} \\
(\mathrm{ppb})\end{array}$ & $\begin{array}{l}\mathrm{NO}_{\mathrm{X}} \\
(\mathrm{ppb})\end{array}$ & $\begin{array}{l}\mathrm{CO} \\
(\mathrm{ppm})\end{array}$ & $\mathrm{T}\left({ }^{\circ} \mathrm{C}\right)$ & $\begin{array}{l}\text { WS } \\
\text { (Knot) }\end{array}$ & $\begin{array}{l}\mathrm{RH} \\
(\%)\end{array}$ & $\begin{array}{l}\text { DWP } \\
\left({ }^{\circ} \mathrm{C}\right)\end{array}$ & $\begin{array}{l}\mathrm{PP} \\
(\mathrm{mm})\end{array}$ \\
\hline \multirow[t]{12}{*}{2004} & Jan & 21.00 & 279.37 & 100.00 & 28.00 & 130.00 & 7.00 & 6.39 & 3.81 & 64.50 & -0.45 & 167.63 \\
\hline & Feb & 30.86 & 292.93 & 53.00 & 27.00 & 76.00 & 5.00 & 9.45 & 6.43 & 43.71 & -2.80 & 8.64 \\
\hline & Mar & 37.63 & 304.94 & 64.00 & 24.00 & 89.00 & 6.00 & 14.18 & 4.61 & 46.84 & 1.70 & 65.28 \\
\hline & Apr & 42.63 & 298.89 & 34.00 & 36.00 & 71.00 & 4.00 & 15.95 & 6.06 & 49.08 & 4.49 & 64.51 \\
\hline & May & 47.33 & 294.71 & 33.00 & 37.00 & 72.00 & 4.00 & 22.10 & 8.10 & 38.97 & 6.25 & 10.67 \\
\hline & Jun & 55.41 & 260.27 & 27.00 & 39.00 & 67.00 & 4.00 & 29.58 & 6.46 & 24.43 & 6.00 & 0.25 \\
\hline & Jul & 58.78 & 269.52 & 24.00 & 33.00 & 57.00 & 3.00 & 29.45 & 6.36 & 31.15 & 9.39 & 10.66 \\
\hline & Aug & 56.35 & 260.54 & 28.00 & 33.00 & 62.00 & 2.00 & 31.48 & 5.64 & 28.33 & 10.05 & 0.00 \\
\hline & Sep & 46.32 & 253.07 & 37.00 & 36.00 & 75.00 & 2.00 & 26.46 & 5.26 & 37.76 & 10.24 & 0.00 \\
\hline & Oct & 36.37 & 252.23 & 54.00 & 43.00 & 99.00 & 4.00 & 20.14 & 4.84 & 40.27 & 5.46 & 3.30 \\
\hline & Nov & 25.61 & 261.19 & 85.00 & 44.00 & 131.00 & 5.00 & 13.00 & 5.37 & 51.43 & 2.33 & 41.92 \\
\hline & Dec & 22.22 & 288.04 & 129.00 & 58.00 & 192.00 & 7.00 & 4.63 & 3.77 & 62.53 & -2.38 & 82.54 \\
\hline \multirow[t]{12}{*}{2005} & Jan & 17.10 & 325.97 & 84.00 & 56.00 & 143.00 & 6.00 & 4.33 & 4.29 & 60.72 & -3.08 & 50.28 \\
\hline & Feb & 32.80 & 339.01 & 46.00 & 52.00 & 100.00 & 5.00 & 4.10 & 5.17 & 63.02 & -3.04 & 49.78 \\
\hline & Mar & 34.70 & 339.67 & 51.00 & 37.00 & 89.00 & 5.00 & 12.36 & 8.57 & 42.86 & -1.39 & 58.17 \\
\hline & Apr & 36.40 & 337.54 & 44.00 & 37.00 & 74.00 & 5.00 & 18.71 & 7.29 & 30.84 & -0.23 & 18.54 \\
\hline & May & 41.70 & 315.68 & 38.00 & 34.00 & 73.00 & 5.00 & 22.09 & 7.15 & 32.85 & 3.85 & 22.61 \\
\hline & Jun & 71.19 & 293.70 & 34.00 & 36.00 & 72.00 & 5.00 & 28.61 & 6.72 & 26.43 & 5.98 & 0.00 \\
\hline & Jul & 51.30 & 283.74 & 43.00 & 41.00 & 85.00 & 6.00 & 32.55 & 5.61 & 27.11 & 10.10 & 0.00 \\
\hline & Aug & 47.30 & 282.13 & 43.00 & 39.00 & 83.00 & 6.00 & 30.64 & 5.21 & 30.23 & 10.02 & 6.35 \\
\hline & Sep & 21.40 & 263.63 & 45.00 & 39.00 & 85.00 & 6.00 & 27.69 & 4.21 & 28.13 & 6.40 & 0.00 \\
\hline & Oct & 15.10 & 257.22 & 67.00 & 39.00 & 107.00 & 7.00 & 21.05 & 4.23 & 33.23 & 3.48 & 0.00 \\
\hline & Nov & 8.00 & 251.71 & 93.00 & 41.00 & 135.00 & 8.00 & 11.26 & 3.34 & 53.73 & 1.59 & 26.67 \\
\hline & Dec & 7.40 & 242.26 & 98.00 & 48.00 & 147.00 & 7.00 & 9.57 & 2.55 & 55.17 & 0.59 & 37.58 \\
\hline \multirow[t]{12}{*}{2006} & Jan & 6.00 & 254.81 & 112.00 & 60.50 & 160.00 & 2.50 & 2.74 & 3.62 & 68.24 & -2.93 & 69.85 \\
\hline & Feb & 8.00 & 279.31 & 106.00 & 49.00 & 144.50 & 8.50 & 9.33 & 5.55 & 44.70 & -3.03 & 42.42 \\
\hline & Mar & 9.00 & 295.06 & 124.00 & 66.00 & 151.00 & 3.00 & 13.81 & 5.90 & 40.28 & -0.39 & 21.59 \\
\hline & Apr & 12.00 & 297.07 & 82.50 & 61.00 & 128.00 & 4.50 & 19.14 & 6.51 & 48.45 & 7.41 & 38.86 \\
\hline & May & 33.00 & 282.90 & 83.00 & 92.00 & 119.00 & 4.00 & 24.55 & 7.12 & 33.01 & 6.02 & 8.13 \\
\hline & Jun & 46.50 & 283.24 & 27.50 & 62.50 & 91.50 & 3.50 & 30.89 & 5.11 & 26.72 & 8.81 & 0.00 \\
\hline & Jul & 60.00 & 283.76 & 43.50 & 54.50 & 98.50 & 4.00 & 31.69 & 5.98 & 35.42 & 13.87 & 1.53 \\
\hline & Aug & 39.00 & 288.79 & 61.50 & 49.50 & 111.50 & 5.50 & 31.58 & 4.59 & 22.76 & 6.90 & 0.00 \\
\hline & Sep & 29.00 & 280.93 & 86.00 & 47.00 & 133.00 & 6.00 & 26.39 & 4.71 & 32.64 & 7.55 & 0.00 \\
\hline & Oct & 20.00 & 277.46 & 85.50 & 42.00 & 128.00 & 6.00 & 21.23 & 5.35 & 44.56 & 7.56 & 22.36 \\
\hline & Nov & 12.00 & 289.39 & 146.00 & 60.50 & 206.00 & 5.00 & 11.25 & 20.37 & 49.54 & 0.34 & 18.04 \\
\hline & Dec & 10.00 & 294.82 & 110.00 & 81.50 & 190.50 & 6.00 & 3.61 & 3.71 & 63.64 & -3.23 & 27.94 \\
\hline
\end{tabular}


Table 4 continued

\begin{tabular}{|c|c|c|c|c|c|c|c|c|c|c|c|c|}
\hline \multirow[t]{3}{*}{ Year } & \multirow[t]{3}{*}{ Month } & \multicolumn{11}{|c|}{ Parameters } \\
\hline & & \multicolumn{2}{|l|}{ Ozone } & \multicolumn{4}{|c|}{ Precursors Parameters } & \multicolumn{5}{|c|}{ Meteorological Parameters } \\
\hline & & $\begin{array}{l}\mathrm{O}_{3} \\
(\mathrm{ppb})\end{array}$ & $\begin{array}{l}\mathrm{O}_{3} \\
(\mathrm{DU})\end{array}$ & $\begin{array}{l}\text { NO } \\
(\mathrm{ppb})\end{array}$ & $\begin{array}{l}\mathrm{NO}_{2} \\
(\mathrm{ppb})\end{array}$ & $\begin{array}{l}\mathrm{NO}_{\mathrm{X}} \\
(\mathrm{ppb})\end{array}$ & $\begin{array}{l}\mathrm{CO} \\
(\mathrm{ppm})\end{array}$ & $\mathrm{T}\left({ }^{\circ} \mathrm{C}\right)$ & $\begin{array}{l}\text { WS } \\
\text { (Knot) }\end{array}$ & $\begin{array}{l}\mathrm{RH} \\
(\%)\end{array}$ & $\begin{array}{l}\text { DWP } \\
\left({ }^{\circ} \mathrm{C}\right)\end{array}$ & $\begin{array}{l}\mathrm{PP} \\
(\mathrm{mm})\end{array}$ \\
\hline \multirow[t]{12}{*}{2007} & Jan & 29.50 & 318.20 & 64.00 & 86.33 & 146.67 & 3.50 & 4.32 & 3.83 & 52.55 & -5.17 & 8.13 \\
\hline & Feb & 24.50 & 312.27 & 79.00 & 80.00 & 150.25 & 3.00 & 7.58 & 6.22 & 55.62 & -1.61 & 46.98 \\
\hline & Mar & 28.50 & 341.83 & 54.50 & 66.25 & 110.50 & 2.75 & 10.04 & 7.39 & 54.78 & 0.49 & 65.78 \\
\hline & Apr & 29.75 & 316.75 & 75.00 & 68.50 & 121.75 & 3.25 & 17.30 & 6.83 & 44.61 & 3.96 & 52.58 \\
\hline & May & 31.50 & 303.01 & 87.25 & 76.00 & 140.50 & 3.00 & 24.52 & 6.44 & 35.56 & 7.00 & 10.41 \\
\hline & Jun & 30.75 & 283.32 & 58.50 & 59.00 & 99.00 & 3.25 & 29.66 & 6.81 & 28.75 & 8.25 & 8.63 \\
\hline & Jul & 34.00 & 272.43 & 75.75 & 65.50 & 117.75 & 3.25 & 31.31 & 6.57 & 27.51 & 9.40 & 1.02 \\
\hline & Aug & 34.25 & 281.18 & 51.00 & 64.25 & 105.00 & 3.25 & 30.75 & 5.23 & 27.83 & 9.16 & 0.00 \\
\hline & Sep & 33.50 & 273.83 & 57.00 & 68.50 & 116.00 & 3.00 & 27.30 & 4.58 & 29.24 & 6.94 & 0.00 \\
\hline & Oct & 28.50 & 268.67 & 60.75 & 79.50 & 130.25 & 3.00 & 20.04 & 4.05 & 37.00 & 4.00 & 3.81 \\
\hline & Nov & 24.00 & 273.24 & 70.25 & 87.00 & 144.00 & 3.50 & 14.61 & 4.69 & 37.75 & -1.55 & 23.37 \\
\hline & Dec & 23.00 & 293.04 & 91.00 & 89.50 & 166.75 & 3.50 & 5.40 & 3.74 & 59.90 & -2.27 & 24.63 \\
\hline \multirow[t]{12}{*}{2008} & Jan & 26.50 & 306.86 & 72.20 & 91.80 & 156.00 & 4.40 & -2.75 & 3.06 & 75.29 & -6.72 & 38.87 \\
\hline & Feb & 30.83 & 299.12 & 66.60 & 71.40 & 129.00 & 2.83 & 4.53 & 5.37 & 54.79 & -4.87 & 27.43 \\
\hline & Mar & 39.50 & 297.82 & 43.20 & 59.20 & 95.60 & 2.83 & 17.04 & 7.32 & 22.96 & -5.75 & 0.00 \\
\hline & Apr & 44.00 & 306.30 & 33.33 & 71.50 & 101.17 & 3.50 & 20.64 & 7.24 & 23.88 & -2.69 & 7.37 \\
\hline & May & 44.50 & 304.00 & 33.17 & 64.50 & 92.50 & 3.40 & 24.08 & 7.97 & 20.30 & -1.61 & 5.59 \\
\hline & Jun & 47.83 & 291.47 & 31.00 & 71.83 & 98.50 & 3.17 & 29.26 & 6.73 & 21.29 & 3.17 & 1.02 \\
\hline & Jul & 45.33 & 284.08 & 36.83 & 72.17 & 102.67 & 3.17 & 31.64 & 6.00 & 21.42 & 5.38 & 0.51 \\
\hline & Aug & 49.67 & 284.88 & 26.83 & 77.83 & 102.00 & 3.00 & 30.46 & 5.26 & 19.16 & 3.11 & 0.25 \\
\hline & Sep & 43.00 & 276.77 & 25.33 & 67.50 & 93.67 & 4.00 & 27.43 & 6.29 & 22.02 & 2.76 & 0.25 \\
\hline & Oct & 31.17 & 273.25 & 29.17 & 72.33 & 102.33 & 2.50 & 20.88 & 5.43 & 31.58 & 1.86 & 5.58 \\
\hline & Nov & 32.00 & 286.27 & 36.17 & 66.00 & 100.67 & 2.60 & 11.28 & 4.79 & 48.96 & 0.25 & 29.98 \\
\hline & Dec & 25.33 & 291.32 & 52.50 & 85.33 & 135.67 & 3.20 & 5.86 & 3.97 & 53.60 & -3.45 & 7.62 \\
\hline \multirow[t]{12}{*}{2009} & Jan & 18.90 & 318.85 & 80.60 & 67.40 & 146.30 & 3.20 & 4.86 & 4.80 & 48.40 & -5.84 & 11.69 \\
\hline & Feb & 18.00 & 311.00 & 92.40 & 56.20 & 144.60 & 3.30 & 8.76 & 7.28 & 47.65 & -2.87 & 47.76 \\
\hline & Mar & 23.10 & 327.15 & 80.10 & 50.30 & 132.10 & 2.54 & 14.30 & 8.09 & 25.51 & -7.32 & 17.02 \\
\hline & Apr & 22.45 & 341.36 & 86.10 & 53.10 & 140.09 & 2.91 & 14.60 & 6.91 & 41.69 & -0.05 & 51.82 \\
\hline & May & 24.82 & 295.85 & 102.36 & 58.10 & 161.36 & 3.36 & 23.68 & 7.32 & 30.94 & 4.23 & 6.61 \\
\hline & Jun & 34.10 & 302.30 & 64.45 & 55.54 & 117.45 & 3.00 & 27.18 & 6.27 & 27.89 & 5.67 & 5.84 \\
\hline & Jul & 27.91 & 283.61 & 81.36 & 55.00 & 137.73 & 3.09 & 32.29 & 7.24 & 17.51 & 2.85 & 0.00 \\
\hline & Aug & 27.00 & 279.30 & 69.54 & 50.09 & 120.36 & 2.91 & 30.08 & 6.18 & 25.86 & 6.82 & 0.00 \\
\hline & Sep & 22.10 & 279.03 & 78.10 & 53.09 & 123.00 & 3.27 & 24.80 & 6.12 & 28.15 & 3.25 & 12.95 \\
\hline & Oct & 18.91 & 269.89 & 90.36 & 57.00 & 131.00 & 3.54 & 19.94 & 4.41 & 26.72 & -1.27 & 2.80 \\
\hline & Nov & 13.45 & 272.83 & 79.00 & 49.91 & 126.18 & 3.45 & 12.10 & 6.17 & 46.55 & 0.11 & 25.65 \\
\hline & Dec & 12.10 & 295.49 & 122.45 & 55.91 & 175.63 & 3.64 & 7.22 & 4.56 & 60.80 & -0.31 & 20.06 \\
\hline
\end{tabular}


Table 4 continued

\begin{tabular}{|c|c|c|c|c|c|c|c|c|c|c|c|c|}
\hline \multirow[t]{3}{*}{ Year } & \multirow[t]{3}{*}{ Month } & \multicolumn{11}{|c|}{ Parameters } \\
\hline & & \multicolumn{2}{|l|}{ Ozone } & \multicolumn{4}{|c|}{ Precursors Parameters } & \multicolumn{5}{|c|}{ Meteorological Parameters } \\
\hline & & $\begin{array}{l}\mathrm{O}_{3} \\
(\mathrm{ppb})\end{array}$ & $\begin{array}{l}\mathrm{O}_{3} \\
(\mathrm{DU})\end{array}$ & $\begin{array}{l}\text { NO } \\
(\mathrm{ppb})\end{array}$ & $\begin{array}{l}\mathrm{NO}_{2} \\
(\mathrm{ppb})\end{array}$ & $\begin{array}{l}\mathrm{NO}_{\mathrm{X}} \\
(\mathrm{ppb})\end{array}$ & $\begin{array}{l}\mathrm{CO} \\
(\mathrm{ppm})\end{array}$ & $\mathrm{T}\left({ }^{\circ} \mathrm{C}\right)$ & $\begin{array}{l}\text { WS } \\
\text { (Knot) }\end{array}$ & $\begin{array}{l}\mathrm{RH} \\
(\%)\end{array}$ & $\begin{array}{l}\text { DWP } \\
\left({ }^{\circ} \mathrm{C}\right)\end{array}$ & $\begin{array}{l}\text { PP } \\
(\mathrm{mm})\end{array}$ \\
\hline \multirow[t]{12}{*}{2010} & Jan & 12.67 & 310.64 & 121.00 & 57.58 & 170.67 & 3.75 & 8.52 & 6.09 & 48.77 & -2.41 & 32.51 \\
\hline & Feb & 21.10 & 337.68 & 114.82 & 55.27 & 167.73 & 3.36 & 8.61 & 5.94 & 48.93 & -2.35 & 40.64 \\
\hline & Mar & 20.00 & 306.92 & 99.50 & 56.25 & 149.83 & 3.50 & 14.61 & 6.72 & 40.67 & -0.53 & 19.81 \\
\hline & Apr & 19.83 & 320.19 & 85.67 & 46.17 & 125.67 & 3.33 & 18.21 & 7.83 & 35.71 & 1.23 & 51.05 \\
\hline & May & 23.75 & 314.85 & 78.58 & 41.58 & 111.83 & 3.00 & 23.73 & 8.58 & 26.92 & 1.58 & 5.08 \\
\hline & Jun & 25.61 & 289.64 & 80.83 & 43.61 & 116.15 & 2.92 & 30.60 & 6.51 & 16.49 & 0.93 & 170.18 \\
\hline & Jul & 31.50 & 290.18 & 67.50 & 45.71 & 111.42 & 3.07 & 32.81 & 6.42 & 18.26 & 3.92 & 120.14 \\
\hline & Aug & 31.78 & 295.14 & 66.93 & 47.64 & 112.21 & 3.14 & 29.67 & 5.56 & 20.71 & 3.63 & 0.00 \\
\hline & Sep & 21.36 & 288.11 & 88.00 & 45.53 & 133.33 & 3.40 & 26.18 & 5.32 & 23.43 & 2.09 & 0.51 \\
\hline & Oct & 16.38 & 264.75 & 105.40 & 45.27 & 150.53 & 4.13 & 22.75 & 5.65 & 26.50 & 1.28 & 1.78 \\
\hline & Nov & 13.86 & 261.89 & 161.87 & 72.00 & 230.87 & 4.40 & 12.90 & 3.21 & 39.47 & -2.13 & 26.92 \\
\hline & Dec & 11.71 & 272.14 & 154.00 & 69.67 & 221.20 & 3.93 & 9.57 & 3.61 & 36.06 & -5.60 & 3.30 \\
\hline \multirow[t]{12}{*}{2011} & Jan & 10.44 & 315.59 & 109.19 & 60.69 & 169.94 & 3.37 & 4.14 & 4.63 & 58.95 & -4.12 & 53.85 \\
\hline & Feb & 14.69 & 332.78 & 61.37 & 49.69 & 111.12 & 2.94 & 6.38 & 7.41 & 48.36 & -4.57 & 12.70 \\
\hline & Mar & 18.67 & 321.71 & 60.69 & 53.00 & 113.63 & 2.56 & 10.66 & 5.81 & 45.58 & -2.84 & 46.73 \\
\hline & Apr & 2.47 & 323.16 & 54.00 & 51.87 & 105.53 & 2.31 & 19.00 & 7.71 & 26.74 & -2.39 & 15.74 \\
\hline & May & 29.13 & 291.45 & 49.20 & 50.93 & 100.40 & 2.69 & 24.21 & 8.60 & 27.62 & 2.60 & 5.84 \\
\hline & Jun & 26.25 & 281.30 & 51.53 & 53.80 & 105.07 & 2.50 & 30.30 & 7.90 & 19.17 & 2.45 & 1.27 \\
\hline & Jul & 25.27 & 282.62 & 51.60 & 50.93 & 101.33 & 2.53 & 32.43 & 6.58 & 17.10 & 3.28 & 0.00 \\
\hline & Aug & 22.93 & 286.40 & 56.00 & 46.43 & 102.29 & 2.60 & 30.32 & 6.50 & 26.87 & 6.21 & 21.33 \\
\hline & Sep & 21.86 & 281.30 & 50.75 & 49.00 & 101.44 & 2.50 & 26.57 & 5.34 & 23.90 & 2.66 & 0.00 \\
\hline & Oct & 19.67 & 271.30 & 74.53 & 53.06 & 127.18 & 2.88 & 16.39 & 6.22 & 45.00 & 0.82 & 105.66 \\
\hline & Nov & 16.69 & 269.00 & 61.82 & 53.82 & 115.47 & 2.59 & 8.01 & 5.00 & 66.28 & 1.61 & 78.73 \\
\hline & Dec & 16.41 & 279.10 & 76.00 & 63.81 & 135.75 & 2.88 & 5.52 & 3.96 & 52.88 & -3.83 & 5.08 \\
\hline \multirow[t]{12}{*}{2012} & Jan & 15.83 & 307.00 & 52.42 & 63.00 & 115.17 & 2.91 & 4.30 & 5.88 & 48.66 & -6.37 & 20.57 \\
\hline & Feb & 18.83 & 331.40 & 38.55 & 41.45 & 78.73 & 2.54 & 3.59 & 6.08 & 52.74 & -6.29 & 49.79 \\
\hline & Mar & 22.91 & 320.60 & 34.83 & 35.25 & 69.08 & 2.20 & 9.32 & 8.69 & 32.14 & -8.30 & 21.59 \\
\hline & Apr & 22.21 & 318.40 & 33.33 & 37.13 & 70.47 & 2.46 & 18.22 & 6.54 & 38.75 & 2.29 & 33.53 \\
\hline & May & 28.40 & 303.00 & 32.19 & 33.69 & 64.75 & 2.07 & 24.37 & 8.59 & 23.79 & 0.75 & 10.66 \\
\hline & Jun & 32.73 & 279.00 & 28.20 & 31.53 & 59.93 & 2.13 & 28.25 & 6.31 & 21.67 & 2.69 & 3.05 \\
\hline & Jul & 26.86 & 278.00 & 43.50 & 36.94 & 80.44 & 2.64 & 30.77 & 6.15 & 23.06 & 5.42 & 7.11 \\
\hline & Aug & 25.73 & 279.30 & 51.50 & 39.25 & 93.06 & 2.71 & 31.02 & 5.48 & 18.41 & 2.95 & 0.25 \\
\hline & Sep & 22.07 & 277.00 & 62.06 & 38.06 & 100.25 & 2.43 & 26.25 & 5.51 & 24.43 & 2.93 & 0.00 \\
\hline & Oct & 17.31 & 271.50 & 80.87 & 37.67 & 118.67 & 2.57 & 19.85 & 5.23 & 33.39 & 1.62 & 13.46 \\
\hline & Nov & 15.77 & 271.00 & 80.21 & 35.93 & 116.00 & 2.53 & 12.70 & 4.22 & 52.34 & 2.15 & 41.65 \\
\hline & Dec & 19.00 & 283.40 & 85.07 & 39.50 & 123.71 & 2.60 & 6.11 & 4.27 & 64.96 & -0.48 & 35.56 \\
\hline
\end{tabular}


Table 4 continued

\begin{tabular}{|c|c|c|c|c|c|c|c|c|c|c|c|c|}
\hline \multirow[t]{3}{*}{ Year } & \multirow[t]{3}{*}{ Month } & \multicolumn{11}{|c|}{ Parameters } \\
\hline & & \multicolumn{2}{|l|}{ Ozone } & \multicolumn{4}{|c|}{ Precursors Parameters } & \multicolumn{5}{|c|}{ Meteorological Parameters } \\
\hline & & $\begin{array}{l}\mathrm{O}_{3} \\
(\mathrm{ppb})\end{array}$ & $\begin{array}{l}\mathrm{O}_{3} \\
\text { (DU) }\end{array}$ & $\begin{array}{l}\text { NO } \\
(\mathrm{ppb})\end{array}$ & $\begin{array}{l}\mathrm{NO}_{2} \\
(\mathrm{ppb})\end{array}$ & $\begin{array}{l}\mathrm{NO}_{\mathrm{X}} \\
(\mathrm{ppb})\end{array}$ & $\begin{array}{l}\mathrm{CO} \\
(\mathrm{ppm})\end{array}$ & $\mathrm{T}\left({ }^{\circ} \mathrm{C}\right)$ & $\begin{array}{l}\text { WS } \\
\text { (Knot) }\end{array}$ & $\begin{array}{l}\mathrm{RH} \\
(\%)\end{array}$ & $\begin{array}{l}\text { DWP } \\
\left({ }^{\circ} \mathrm{C}\right)\end{array}$ & $\begin{array}{l}\mathrm{PP} \\
(\mathrm{mm})\end{array}$ \\
\hline \multirow[t]{12}{*}{2013} & Jan & 21.71 & 301.00 & 85.88 & 42.11 & 126.23 & 2.81 & 6.25 & 5.85 & 45.63 & -5.58 & 23.88 \\
\hline & Feb & 19.08 & 329.00 & 68.29 & 38.00 & 104.76 & 2.62 & 8.78 & 6.07 & 44.34 & -3.65 & 129.79 \\
\hline & Mar & 22.85 & 319.10 & 48.65 & 31.76 & 77.82 & 2.43 & 13.52 & 7.49 & 35.15 & -3.82 & 20.06 \\
\hline & Apr & 24.54 & 315.40 & 32.88 & 29.29 & 62.29 & 2.25 & 18.14 & 7.11 & 30.54 & -1.22 & 8.64 \\
\hline & May & 23.45 & 307.00 & 26.71 & 27.41 & 54.12 & 2.09 & 22.20 & 8.57 & 28.37 & 1.49 & 13.19 \\
\hline & Jun & 25.00 & 283.00 & 46.53 & 36.07 & 82.53 & 2.38 & 28.39 & 8.00 & 20.77 & 1.89 & 0.00 \\
\hline & Jul & 26.33 & 281.60 & 56.61 & 39.85 & 93.46 & 2.73 & 31.79 & 6.78 & 21.93 & 5.59 & 0.00 \\
\hline & Aug & 21.64 & 282.00 & 60.58 & 35.92 & 95.83 & 2.50 & 29.48 & 6.32 & 24.08 & 5.40 & 0.00 \\
\hline & Sep & 21.64 & 275.40 & 77.10 & 34.54 & 109.36 & 2.58 & 27.79 & 6.38 & 18.67 & 0.34 & 0.00 \\
\hline & Oct & 20.55 & 273.40 & 74.22 & 38.40 & 104.70 & 3.06 & 18.94 & 5.57 & 31.50 & -0.08 & 2.29 \\
\hline & Nov & 15.38 & 279.00 & 67.80 & 40.10 & 105.50 & 2.60 & 12.38 & 4.27 & 53.52 & 2.32 & 22.61 \\
\hline & Dec & 20.85 & 284.20 & 61.92 & 37.08 & 98.08 & 2.41 & 5.10 & 5.61 & 50.79 & -5.05 & 28.19 \\
\hline \multirow[t]{12}{*}{2014} & Jan & 19.33 & 301.73 & 72.11 & 35.56 & 107.67 & 2.27 & 5.45 & 5.26 & 54.36 & -3.90 & 6.35 \\
\hline & Feb & 17.11 & 326.44 & 93.62 & 40.62 & 134.00 & 2.33 & 5.18 & 5.07 & 44.68 & -7.27 & 10.16 \\
\hline & Mar & 37.93 & 317.50 & 40.89 & 42.33 & 82.56 & 2.20 & 12.52 & 8.18 & 36.58 & -3.44 & 8.13 \\
\hline & Apr & 20.54 & 313.30 & 36.89 & 36.89 & 73.11 & 2.15 & 18.20 & 7.44 & 32.38 & -0.35 & 9.66 \\
\hline & May & 25.25 & 307.60 & 34.42 & 35.08 & 68.92 & 2.42 & 24.45 & 7.72 & 24.73 & 1.16 & 5.59 \\
\hline & Jun & 25.85 & 291.50 & 36.40 & 37.60 & 73.40 & 2.36 & 29.56 & 8.00 & 18.48 & 1.32 & 1.02 \\
\hline & Jul & 37.81 & 279.40 & 33.85 & 27.93 & 58.57 & 2.92 & 32.21 & 6.78 & 19.34 & 4.41 & 2.29 \\
\hline & Aug & 26.15 & 279.50 & 48.75 & 40.92 & 89.42 & 3.67 & 31.72 & 6.16 & 16.08 & 1.43 & 0.00 \\
\hline & Sep & 21.07 & 272.50 & 76.21 & 38.21 & 113.64 & 2.93 & 28.06 & 6.21 & 19.04 & 0.72 & 0.00 \\
\hline & Oct & 16.20 & 271.70 & 87.84 & 41.38 & 128.69 & 2.87 & 18.34 & 6.57 & 37.65 & 2.37 & 10.16 \\
\hline & Nov & 14.00 & 286.00 & 98.23 & 47.77 & 145.85 & 3.07 & 9.89 & 4.58 & 49.23 & -1.22 & 12.19 \\
\hline & Dec & 12.07 & 285.40 & 108.12 & 49.12 & 157.19 & 3.28 & 7.33 & 4.39 & 53.61 & -2.01 & 22.10 \\
\hline \multirow[t]{12}{*}{2015} & Jan & 14.39 & 305.50 & 98.33 & 51.94 & 150.39 & 2.88 & 6.91 & 5.07 & 42.41 & -5.67 & 7.37 \\
\hline & Feb & 16.41 & 340.30 & 74.50 & 47.17 & 121.55 & 2.67 & 8.34 & 6.00 & 47.34 & -3.22 & 10.91 \\
\hline & Mar & 18.59 & 326.80 & 54.29 & 51.59 & 105.76 & 2.29 & 11.42 & 6.89 & 41.90 & -2.39 & 29.72 \\
\hline & Apr & 21.12 & 314.30 & 50.65 & 44.76 & 95.35 & 2.12 & 19.22 & 8.29 & 23.20 & -4.03 & 15.24 \\
\hline & May & 22.24 & 305.40 & 44.61 & 44.22 & 88.72 & 2.17 & 25.12 & 7.61 & 20.51 & -0.74 & 4.32 \\
\hline & Jun & 22.83 & 286.80 & 45.44 & 44.33 & 89.72 & 2.28 & 31.47 & 6.93 & 16.02 & 1.17 & 0.00 \\
\hline & Jul & 28.82 & 287.50 & 55.88 & 47.23 & 103.12 & 2.41 & 31.90 & 5.98 & 18.96 & 3.49 & 9.65 \\
\hline & Aug & 25.94 & 287.60 & 69.94 & 54.88 & 124.88 & 2.53 & 30.68 & 5.65 & 21.18 & 3.95 & 0.00 \\
\hline & Sep & 24.06 & 292.60 & 52.47 & 52.76 & 105.47 & 2.35 & 25.46 & 5.42 & 26.18 & 3.18 & 1.27 \\
\hline & Oct & 42.44 & 280.90 & 50.11 & 56.39 & 106.28 & 2.67 & 20.68 & 5.78 & 38.57 & 4.48 & 9.90 \\
\hline & Nov & 23.42 & 294.20 & 62.53 & 36.87 & 99.47 & 2.94 & 10.59 & 4.89 & 50.11 & -0.34 & 36.32 \\
\hline & Dec & 8.22 & 290.90 & 74.39 & 50.44 & 124.67 & 2.72 & 5.00 & 4.51 & 61.62 & -2.29 & 20.33 \\
\hline
\end{tabular}


Table 4 continued

\begin{tabular}{|c|c|c|c|c|c|c|c|c|c|c|c|c|}
\hline \multirow[t]{3}{*}{ Year } & \multirow[t]{3}{*}{ Month } & \multicolumn{11}{|c|}{ Parameters } \\
\hline & & \multicolumn{2}{|l|}{ Ozone } & \multicolumn{4}{|c|}{ Precursors Parameters } & \multicolumn{5}{|c|}{ Meteorological Parameters } \\
\hline & & $\begin{array}{l}\mathrm{O}_{3} \\
(\mathrm{ppb})\end{array}$ & $\begin{array}{l}\mathrm{O}_{3} \\
(\mathrm{DU})\end{array}$ & $\begin{array}{l}\text { NO } \\
(\mathrm{ppb})\end{array}$ & $\begin{array}{l}\mathrm{NO}_{2} \\
(\mathrm{ppb})\end{array}$ & $\begin{array}{l}\mathrm{NO}_{X} \\
(\mathrm{ppb})\end{array}$ & $\begin{array}{l}\mathrm{CO} \\
(\mathrm{ppm})\end{array}$ & $\mathrm{T}\left({ }^{\circ} \mathrm{C}\right)$ & $\begin{array}{l}\text { WS } \\
\text { (Knot) }\end{array}$ & $\begin{array}{l}\mathrm{RH} \\
(\%)\end{array}$ & $\begin{array}{l}\text { DWP } \\
\left({ }^{\circ} \mathrm{C}\right)\end{array}$ & $\begin{array}{l}\text { PP } \\
(\mathrm{mm})\end{array}$ \\
\hline \multirow[t]{12}{*}{2016} & Jan & 15.91 & 300.90 & 81.35 & 51.47 & 132.82 & 2.56 & 7.02 & 5.76 & 46.98 & -4.28 & 36.58 \\
\hline & Feb & 34.73 & 322.40 & 77.19 & 54.94 & 132.12 & 2.65 & 9.83 & 6.04 & 37.46 & -5.24 & 5.34 \\
\hline & Mar & 15.57 & 316.70 & 53.50 & 50.00 & 102.50 & 2.33 & 13.66 & 8.75 & 35.89 & -2.80 & 24.64 \\
\hline & Apr & 16.40 & 321.80 & 54.12 & 53.75 & 106.44 & 2.12 & 17.64 & 7.57 & 36.48 & 0.39 & 20.82 \\
\hline & May & 22.83 & 297.50 & 44.00 & 49.19 & 91.00 & 1.80 & 24.85 & 8.47 & 26.39 & 2.14 & 10.67 \\
\hline & Jun & 28.00 & 290.30 & 45.36 & 63.43 & 106.07 & 2.00 & 28.64 & 8.14 & 19.23 & 1.05 & 0.00 \\
\hline & Jul & 27.63 & 280.20 & 52.10 & 55.45 & 107.27 & 2.57 & 31.58 & 7.03 & 22.31 & 5.55 & 0.00 \\
\hline & Aug & 26.64 & 283.00 & 76.75 & 62.42 & 139.00 & 2.69 & 30.14 & 5.19 & 18.00 & 2.18 & 0.00 \\
\hline & Sep & 19.79 & 272.90 & 90.10 & 57.91 & 147.91 & 2.73 & 27.24 & 6.66 & 21.43 & 1.27 & 0.00 \\
\hline & Oct & 15.25 & 272.80 & 116.45 & 53.18 & 169.73 & 2.67 & 19.45 & 4.71 & 28.15 & -0.79 & 0.51 \\
\hline & Nov & 12.00 & 276.40 & 135.42 & 64.58 & 200.00 & 3.21 & 9.80 & 4.61 & 41.48 & -3.88 & 11.17 \\
\hline & Dec & 7.85 & 279.90 & 129.54 & 53.25 & 171.75 & 3.27 & 6.28 & 5.14 & 52.64 & -3.96 & 58.68 \\
\hline \multirow[t]{12}{*}{2017} & Jan & 9.27 & 301.10 & 102.37 & 58.31 & 160.75 & 2.94 & 5.53 & 5.21 & 49.88 & -4.95 & 23.12 \\
\hline & Feb & 11.56 & 334.00 & 81.88 & 61.06 & 143.00 & 3.00 & 5.10 & 5.87 & 47.25 & -6.57 & 31.75 \\
\hline & Mar & 27.57 & 326.70 & 45.82 & 50.23 & 96.29 & 2.20 & 11.21 & 6.91 & 46.32 & -1.26 & 36.57 \\
\hline & Apr & 23.64 & 297.50 & 46.55 & 43.94 & 90.56 & 2.35 & 17.70 & 6.81 & 37.73 & 1.06 & 33.52 \\
\hline & May & 26.43 & 299.20 & 52.05 & 47.11 & 99.11 & 2.50 & 25.27 & 7.21 & 24.26 & 0.26 & 20.83 \\
\hline & Jun & 31.00 & 288.40 & 49.11 & 45.28 & 96.18 & 2.44 & 29.80 & 7.63 & 16.87 & 0.03 & 0.00 \\
\hline & Jul & 32.18 & 286.00 & 46.80 & 46.47 & 93.13 & 2.53 & 31.71 & 5.70 & 18.65 & 2.93 & 9.40 \\
\hline & Aug & 30.18 & 280.20 & 55.60 & 53.4 & 108.87 & 2.56 & 30.35 & 5.62 & 19.12 & 3.10 & 0.00 \\
\hline & Sep & 25.00 & 272.30 & 87.20 & 60.00 & 147.00 & 2.44 & 27.23 & 5.26 & 20.41 & 1.00 & 0.00 \\
\hline & Oct & 15.23 & 269.30 & 109.44 & 53.00 & 162.31 & 2.42 & 19.64 & 5.32 & 27.98 & -1.25 & 4.32 \\
\hline & Nov & 11.65 & 285.70 & 103.80 & 53.33 & 156.93 & 2.42 & 13.71 & 5.43 & 32.39 & -3.09 & 0.00 \\
\hline & Dec & 7.65 & 287.90 & 139.12 & 65.25 & 204.06 & 3.05 & 8.26 & 4.31 & 40.00 & -5.11 & 4.06 \\
\hline \multirow[t]{12}{*}{2018} & Jan & 8.53 & 313.20 & 118.53 & 56.27 & 174.80 & 2.35 & 6.11 & 5.34 & 47.00 & -5.69 & 31.75 \\
\hline & Feb & 10.18 & 331.40 & 89.40 & 59.67 & 149.20 & 2.41 & 8.44 & 5.15 & 55.95 & -0.39 & 27.43 \\
\hline & Mar & 19.47 & 327.70 & 54.87 & 40.33 & 94.93 & 2.29 & 17.07 & 8.38 & 27.15 & -3.85 & 5.32 \\
\hline & Apr & 22.72 & 333.90 & 37.07 & 41.07 & 77.64 & 1.76 & 16.80 & 6.25 & 37.08 & 0.05 & 54.35 \\
\hline & May & 29.53 & 319.60 & 35.00 & 40.54 & 74.54 & 1.37 & 21.22 & 7.18 & 37.46 & 4.62 & 24.88 \\
\hline & Jun & 34.62 & 288.50 & 36.83 & 38.75 & 74.50 & 1.56 & 28.86 & 6.30 & 22.26 & 3.25 & 5.58 \\
\hline & Jul & 36.81 & 282.00 & 46.33 & 41.42 & 86.00 & 1.69 & 34.10 & 5.65 & 14.09 & 1.57 & 0.00 \\
\hline & Aug & 26.87 & 279.10 & 53.33 & 39.08 & 91.33 & 1.71 & 31.73 & 6.00 & 20.00 & 4.62 & 0.00 \\
\hline & Sep & 22.69 & 281.80 & 70.08 & 42.92 & 111.69 & 1.76 & 27.15 & 5.58 & 21.17 & 1.27 & 0.25 \\
\hline & Oct & 13.87 & 280.20 & 76.78 & 40.93 & 116.93 & 1.82 & 19.30 & 5.69 & 40.36 & 4.03 & 14.23 \\
\hline & Nov & 10.33 & 278.30 & 78.08 & 49.38 & 126.77 & 2.00 & 10.91 & 4.29 & 59.14 & 2.48 & 72.39 \\
\hline & Dec & 7.93 & 284.40 & 101.00 & 58.64 & 158.78 & 2.18 & 8.99 & 4.71 & 51.50 & -1.09 & 26.92 \\
\hline
\end{tabular}


Table 4 continued

\begin{tabular}{|c|c|c|c|c|c|c|c|c|c|c|c|c|}
\hline \multirow[t]{3}{*}{ Year } & \multirow[t]{3}{*}{ Month } & \multicolumn{11}{|c|}{ Parameters } \\
\hline & & \multicolumn{2}{|c|}{ Ozone } & \multicolumn{4}{|c|}{ Precursors Parameters } & \multicolumn{5}{|c|}{ Meteorological Parameters } \\
\hline & & $\begin{array}{l}\mathrm{O}_{3} \\
(\mathrm{ppb})\end{array}$ & $\begin{array}{l}\mathrm{O}_{3} \\
\text { (DU) }\end{array}$ & $\begin{array}{l}\text { NO } \\
(\mathrm{ppb})\end{array}$ & $\begin{array}{l}\mathrm{NO}_{2} \\
(\mathrm{ppb})\end{array}$ & $\begin{array}{l}\mathrm{NO}_{X} \\
(\mathrm{ppb})\end{array}$ & $\begin{array}{l}\mathrm{CO} \\
(\mathrm{ppm})\end{array}$ & $\mathrm{T}\left({ }^{\circ} \mathrm{C}\right)$ & $\begin{array}{l}\text { WS } \\
\text { (Knot) }\end{array}$ & $\begin{array}{l}\text { RH } \\
(\%)\end{array}$ & $\begin{array}{l}\text { DWP } \\
\left({ }^{\circ} \mathrm{C}\right)\end{array}$ & $\begin{array}{l}\text { PP } \\
(\mathrm{mm})\end{array}$ \\
\hline \multirow[t]{12}{*}{2019} & Jan & 9.47 & 282.80 & 90.07 & 57.36 & 146.78 & 2.35 & 5.94 & 5.81 & 51.86 & -3.98 & 49.29 \\
\hline & Feb & 13.00 & 320.04 & 63.21 & 54.64 & 117.43 & 1.87 & 7.23 & 6.35 & 44.44 & -4.98 & 18.53 \\
\hline & Mar & 18.94 & 347.80 & 39.94 & 44.81 & 84.37 & 1.29 & 10.48 & 7.11 & 43.09 & -2.81 & 62.48 \\
\hline & Apr & 24.71 & 327.90 & 36.76 & 41.41 & 77.88 & 1.11 & 15.38 & 7.12 & 34.07 & -0.35 & 65.02 \\
\hline & May & 28.00 & 312.10 & 39.88 & 40.47 & 79.88 & 1.22 & 24.26 & 7.96 & 25.34 & 1.52 & 6.09 \\
\hline & Jun & 36.35 & 293.90 & 40.83 & 45.17 & 85.11 & 1.41 & 30.40 & 5.84 & 18.13 & 2.20 & 1.02 \\
\hline & Jul & 32.41 & 284.60 & 48.39 & 47.06 & 94.61 & 1.65 & 33.06 & 7.24 & 18.42 & 4.06 & 0.00 \\
\hline & Aug & 30.50 & 284.50 & 56.39 & 48.11 & 103.89 & 1.76 & 30.61 & 6.12 & 20.52 & 3.76 & 0.00 \\
\hline & Sep & 21.89 & 273.90 & 72.50 & 44.61 & 116.56 & 1.94 & 26.68 & 6.20 & 24.53 & 2.93 & 0.00 \\
\hline & Oct & 15.37 & 280.10 & 74.56 & 50.56 & 124.44 & 1.94 & 19.59 & 5.03 & 40.02 & 3.04 & 66.82 \\
\hline & Nov & 9.68 & 290.50 & 97.88 & 57.41 & 154.65 & 2.00 & 9.34 & 4.36 & 57.45 & 0.26 & 21.84 \\
\hline & Dec & 7.26 & 300.50 & 122.28 & 66.11 & 188.06 & 4.78 & 7.89 & 4.42 & 56.81 & -0.62 & 24.13 \\
\hline \multirow[t]{12}{*}{2020} & Jan & 7.84 & 332.90 & 85.22 & 58.39 & 143.06 & 1.78 & 4.02 & 5.11 & 57.95 & -4.05 & 25.90 \\
\hline & Feb & 13.33 & 321.70 & 65.67 & 50.11 & 115.22 & 1.59 & 7.25 & 7.90 & 46.75 & -4.63 & 86.38 \\
\hline & Mar & 21.47 & 323.40 & 32.39 & 41.11 & 73.28 & 1.13 & 13 & 6.21 & 41.37 & -1.42 & 58.41 \\
\hline & Apr & 21.63 & 330.80 & 29.78 & 37.67 & 67.11 & 3.75 & 15.09 & 6.86 & 48.37 & 2.83 & 96.25 \\
\hline & May & 28.05 & 293.10 & 32.00 & 38.89 & 70.50 & 1.18 & 24.14 & 7.47 & 26.28 & 1.49 & 23.88 \\
\hline & Jun & 33.39 & 279.00 & 38.53 & 44.18 & 82.29 & 1.33 & 29.67 & 7.65 & 17.46 & 0.21 & 0.76 \\
\hline & Jul & 36.26 & 278.80 & 34.22 & 45.22 & 79.05 & 1.28 & 31.20 & 6.27 & 21.02 & 4.86 & 0.25 \\
\hline & Aug & 29.68 & 273.10 & 46.78 & 42.22 & 88.17 & 1.33 & 28.87 & 6.78 & 26.46 & 6.12 & 0.00 \\
\hline & Sep & 23.21 & 275.40 & 68.50 & 48.00 & 115.78 & 3.11 & 25.98 & 5.27 & 23.60 & 2.34 & 0.00 \\
\hline & Oct & 19.16 & 266.50 & 94.44 & 57.56 & 151.44 & 1.94 & 18.27 & 4.42 & 32.71 & -0.32 & 16.51 \\
\hline & Nov & 9.84 & 269.90 & 75.17 & 49.11 & 123.89 & 1.59 & 11.48 & 4.42 & 57.20 & 1.50 & 72.39 \\
\hline & Dec & 6.67 & 296.30 & 102.11 & 60.44 & 161.94 & 2.06 & 5.01 & 4.08 & 67.71 & -0.79 & 39.12 \\
\hline
\end{tabular}

management methods, improvement in public transportation such as metro, prevention of expansion and continuation of polluting industries in urban areas, application of traffic restrictions may be considered the main factors in reducing the amount of ozone concentration in Tehran during the second decade. The average annual ozone concentration in 2020 compared to 2001 has increased by $23.77 \%$. This is due to changes in meteorological conditions and climate change.

The seasonal variation in ozone shows low concentrations in late autumn and winter and high concentrations in late spring and early summer. The seasonal changes in ozone precursors are different the pattern of seasonal changes in ozone. In general, increasing precursors of tropospheric ozone concentrations the length of the day is related to human activities and traffic. Correlations of $\mathrm{O}_{3}$ with its precursors as well as meteorological parameters were investigated using regression analysis. Pearson correlation was used to show the effect of each parameter on average ozone concentration. The results showed that $\mathrm{O}_{3}$ had a positive and significant correlation with temperature, wind speed and dew point and a negative correlation with relative humidity and rainfall rate. The concentration of ozone precursors has a significant positive correlation with moisture and rainfall and a significant negative correlation with temperature, wind speed and dew point. In general, temperature and relative humidity have the highest significant 
correlation with tropospheric ozone concentration. Maximum tropospheric ozone concentrations occur at high temperatures and low humidity.

The results show that seasonal changes in $\mathrm{O}_{3}$ concentration and its precursors are not fully consistent with seasonal changes in meteorological parameters. This three-atom oxygen combination is a dangerous air pollutant due to natural and human factors affecting air quality such as stratospheric air infiltration and increasing concentration of ozone precursors as the result of industrial activities, vehicle traffic and pollutants in Tehran. The correlation of tropospheric ozone data with the climatic data, especially temperature in Tehran, as well as the analysis of $\mathrm{O}_{3}$ variations during the last two decades, indicates that the cybernetic climate system is one of the main controllers of the tropospheric ozone concentration.

Acknowledgements Special thanks are extended to Tehran Air Quality Control Company (AQCC), Institute of Geophysics of the University of Tehran (IGUT) and Department of Environment (DOE) for efficient helps in providing the database of this study.

Author contribution Faezeh Borhani took part in conception or design of the work, data collection, data analysis and interpretation, drafting the article and final approval of the version to be published, Majid Shafiepour Motlagh involved in conception or design of the work, critical revision of the article and final approval of the version to be published, Andreas Stohl participated in data analysis and interpretation, critical revision of the article and final approval of the version to be published, Yousef Rashidi took part in data collection and final approval of the version to be published, and Amir Houshang Ehsani participated in data collection and final approval of the version to be published.

Funding The authors did not receive support from any organization for the submitted work.

Data availability The database analyzed during the present study are available from the corresponding author on reasonable request.

\section{Declarations}

Conflict of interest The authors declare that they have no conflict of interest.

Consent to participate Informed consent was obtained from all individual participants included in the study.

\section{Appendix}

See Table 4.

\section{References}

Agathokleous, E., Feng, Z., Oksanen, E., Sicard, P., Wang, Q., Saitanis, C. J., ... \& Paoletti, E. (2020). Ozone affects plant, insect, and soil microbial communities: A threat to terrestrial ecosystems and biodiversity. Science advances, 6(33), eabc1176.

Akbar, B. A., \& Sharee, P. Z. (2007). Analysis of surface ozone variations near geophysics synoptic station for the year 2002. Journal of Environmental Studies, 33, 63-74.

Archibald, A. T., Neu, J. L., Elshorbany, Y. F., Cooper, O. R., Young, P. J., Akiyoshi, H., et al. (2020). Tropospheric Ozone Assessment ReportA critical review of changes in the tropospheric ozone burden and budget from 1850 to 2100. Elementa: Science of the Anthropocene, 8(1), 034.

Borhani, F., Motlagh, M. S., Stohl, A., Rashidi, Y., \& Ehsani, A. H. (2021). Changes in short-lived climate pollutants during the COVID-19 pandemic in Tehran. Iran. Environmental Monitoring and Assessment, 193(6), 1-12.

Brook, R. D., Franklin, B., Cascio, W., Hong, Y., Howard, G., Lipsett, M., et al. (2004). Air pollution and cardiovascular disease: A statement for healthcare professionals from the expert panel on population and prevention science of the American heart association. Circulation, 109(21), 2655-2671.

Brunekreef, B., \& Holgate, S. T. (2002). Air Pollution and Health. the Lancet, 360(9341), 1233-1242.

Calvert, J. G., Orlando, J. J., Stockwell, W. R., \& Wallington, T. J. (2015). The mechanisms of reactions influencing atmospheric ozone. Oxford University Press.

Camalier, L., Cox, W., \& Dolwick, P. (2007). The effects of meteorology on ozone in urban areas and their use in assessing ozone trends. Atmospheric Environment, 41(33), 7127-7137.

Cao, L., Gao, M., Li, S., Yi, Z., \& Meng, X. (2019). Sensitivity analysis of the dependence of the carbon bond mechanism IV (CBM-IV) on the initial air composition under an urban condition. Atmospheric Environment, 215, 116860.

Chelani, A. B. (2009). Statistical persistence analysis of hourly ground level ozone concentrations in Delhi. Atmospheric Research, 92(2), 244-250.

Colls, J., \& Tiwary, A. (2009). Air pollution: Measurement, modelling and mitigation. CRC Press.

Cross, J. M., \& Pierson, R. (2013). Short-Lived Climate Pollutants: why are They Important. Washington: EESI (Environment and Energy Study Institute), 202, 628-1400.

Crutzen, P. J. (1974). Photochemical reactions initiated by and influencing ozone in unpolluted tropospheric air. Tellus, 26(1-2), 47-57.

Danielsen, E. F. (1968). Stratospheric-tropospheric exchange based on radioactivity, ozone and potential vorticity. Journal of Atmospheric Sciences, 25(3), 502-518. 
Duenas, C., Fernandez, M. C., Canete, S., Carretero, J., \& Liger, E. (2002). Assessment of ozone variations and meteorological effects in an urban area in the Mediterranean Coast. Science of the Total Environment, 299(1-3), 97-113.

EEA, European Environment Agency. (2018). https://www.eea. europa.eu/

Elminir, H. K. (2005). Dependence of urban air pollutants on meteorology. Science of the Total Environment, 350(1-3), 225-237.

Faridi, S., Shamsipour, M., Krzyzanowski, M., Künzli, N., Amini, H., Azimi, F., \& Naddafi, K. (2018). Long-term trends and health impact of PM2. 5 and $\mathrm{O}_{3}$ in Tehran, Iran, 2006-2015. Environment International, 114, 37-49.

Feng, Z., De Marco, A., Anav, A., Gualtieri, M., Sicard, P., Tian, H., ... \& Paoletti, E. (2019). Economic losses due to ozone impacts on human health, forest productivity and crop yield across China. Environment international, 131, 104966.

Fiore, A. M., Naik, V., \& Leibensperger, E. M. (2015). Air quality and climate connections. Journal of the Air \& Waste Management Association, 65(6), 645-685.

Fishman, J., Wozniak, A. E., \& Creilson, J. K. (2003). Global distribution of tropospheric ozone from satellite measurements using the empirically corrected tropospheric ozone residual technique: Identification of the regional aspects of air pollution. Atmospheric Chemistry and Physics, 3(4), 893-907.

Forster, P., Ramaswamy, V., Artaxo, P., Berntsen, T., Betts, R., Fahey, D. W., ... \& Van Dorland, R. (2007). Changes in atmospheric constituents and in radiative forcing. Chapter 2. In Climate change 2007. The physical science basis..

Fowler, D., Amann, M., Anderson, R., Ashmore, M., Cox, P., Depledge, M., ... \& Stevenson, D. (2008). Ground-level ozone in the 21st century: future trends, impacts and policy implications. The Royal Society..

Ghiasodin, M., \& Sourati, L. (2014). Ozone concentration and meteorological parameters alternations investigation in Air Quality Control Company to Aqdasieh station in 7 months (from Oct. 2007 to Apr. 2008) in Tehran. Journal of Environmental Science and Technology, 16(4), 77-83.

Giovanni, NASA's Goddard Earth Sciences Data and Information Services Center. (2020). https://giovanni.gsfc.nasa. gov/giovanni/

Godish, T., Davis, W. T., \& Fu, J. S. (2003). Air Quality (4th ed.). Lewis Publishers.

Guicherit, R., \& Van Dop, H. (1977). Photochemical production of ozone in Western Europe (1971-1975) and its relation to meteorology. Atmospheric Environment, 11(2), 145-155.

Han, H., Liu, J., Shu, L., Wang, T., \& Yuan, H. (2020). Local and synoptic meteorological influences on daily variability in summertime surface ozone in eastern China. Atmospheric Chemistry and Physics, 20(1), 203-222.

Ibarra-Berastegi, G., Elias, A., Barona, A., Saenz, J., Ezcurra, A., \& de Argandoña, J. D. (2008). From diagnosis to prognosis for forecasting air pollution using neural networks: Air pollution monitoring in Bilbao. Environmental Modelling \& Software, 23(5), 622-637.

Javanbakht Amiri, S., \& Khatami, S. H. (2012). The Study of the correlation between air quality index pollution and meteorological parameters in Tehran with regression analysis approach. Human \& Environment, 10(34), 15-28.
Jerrett, M., Burnett, R. T., Pope III, C. A., Ito, K., Thurston, G., Krewski, D., ... \& Thun, M. (2009). Long-term ozone exposure and mortality. New England Journal of Medicine, 360(11), 1085-1095.

Jo, W. K., \& Park, J. H. (2005). Characteristics of roadside air pollution in Korean metropolitan city (Daegu) over last 5 to 6 years: Temporal variations, standard exceedances, and dependence on meteorological conditions. Chemosphere, 59(11), 1557-1573.

Junge, C. E. (1962). Global ozone budget and exchange between stratosphere and troposphere. Tellus, 14(4), 363-377.

Karimi, s. . (2014). Synoptic analysis of tropospheric ozone variations case study: Tehran metropolitan. Journal of Geographical Sciences, 14(32), 7-26.

Kayes, I., Shahriar, S. A., Hasan, K., Akhter, M., Kabir, M. M., \& Salam, M. A. (2019). The relationships between meteorological parameters and air pollutants in an urban environment. Global Journal of Environmental Science and Management, 5(3), 265-278.

Keyhani, A., Ghasemi-Varnamkhasti, M., Khanali, M., \& Abbaszadeh, R. (2010). An assessment of wind energy potential as a power generation source in the capital of Iran. Tehran. Energy, 35(1), 188-201.

Kindbom, K., Nielsen, O.K., Saarinen, K., Jonsson, K., Aasestad, K. (2019). Policy Brief-Emissions of Short-Lived Climate Pollutants (SLCP): Emission factors, scenarios and reduction potentials. Nordic Council of Ministers.

Kirtman, B., Power, S. B., Adedoyin, A. J., Boer, G. J., Bojariu, R., Camilloni, I., et al. (2013). Near-term climate change: projections and predictability. In: Climate Change 2013: The Physical Science Basis. IPCC Working Group I Contribution to AR5. Eds. IPCC, Cambridge: Cambridge University Press.

Kovač-Andrić, E., Brana, J., \& Gvozdić, V. (2009). Impact of meteorological factors on ozone concentrations modelled by time series analysis and multivariate statistical methods. Ecological Informatics, 4(2), 117-122.

Li, K., Jacob, D. J., Liao, H., Shen, L., Zhang, Q., \& Bates, K. H. (2019). Anthropogenic drivers of 2013-2017 trends in summer surface ozone in China. Proceedings of the National Academy of Sciences, 116(2), 422-427.

Li, Y., Lau, A. K., Fung, J. C., Zheng, J., \& Liu, S. (2013). Importance of NOx control for peak ozone reduction in the Pearl River Delta region. Journal of Geophysical Research: Atmospheres, 118(16), 9428-9443.

Liu, H., Zhang, M., Han, X., Li, J., \& Chen, L. (2019). Episode analysis of regional contributions to tropospheric ozone in Beijing using a regional air quality model. Atmospheric Environment, 199, 299-312.

Liu, S. C., Trainer, M., Fehsenfeld, F. C., Parrish, D. D., Williams, E. J., Fahey, D. W., \& Murphy, P. C. (1987). Ozone production in the rural troposphere and the implications for regional and global ozone distributions. Journal of Geophysical Research: Atmospheres, 92(D4), 4191-4207.

Lu, X., Zhang, L., \& Shen, L. (2019). Meteorology and climate influences on tropospheric ozone: A review of natural sources, chemistry, and transport patterns. Current Pollution Reports, 5(4), 238-260.

Malley, C. S., Henze, D. K., Kuylenstierna, J. C., Vallack, H. W., Davila, Y., Anenberg, S. C., ... \& Ashmore, M. R. (2017). Updated global estimates of respiratory mortality 
in adults $\geq 30$ years of age attributable to long-term ozone exposure. Environmental health perspectives, 125(8), 087021.

McPeters, R. D., Bhartia, P. K., Krueger, A. J., Herman, J. R., Wellemeyer, C. G., Seftor, C. J., ... \& Cebula, R. P. (1998). Earth probe total ozone mapping spectrometer (TOMS): data products user's guide.

Monks, P. S., Archibald, A. T., Colette, A., Cooper, O., Coyle, M., Derwent, R., et al. (2015). Tropospheric ozone and its precursors from the urban to the global scale from air quality to short-lived climate forcer. Atmospheric Chemistry and Physics, 15(15), 8889-8973.

Mulumba, J. P., Venkataraman, S., \& Afullo, T. J. O. (2015). Modeling tropospheric ozone climatology over Irene (South Africa) using retrieved remote sensing and groundbased measurement data. J. Remote Sens. Gis, 4(3), 1-11.

Murao, N., Ohta, S., Furuhashi, N., \& Mizoguchi, I. (1990). The causes of elevated concentrations of ozone in Sapporo. Atmospheric Environment. Part a. General Topics, 24(6), 1501-1507.

Özbay, B. (2012). Modeling the effects of meteorological factors on $\mathrm{SO} 2$ and PM10 concentrations with statistical approaches. Clean-Soil, Air, Water, 40(6), 571-577.

Paoletti, E., De Marco, A., Beddows, D. C., Harrison, R. M., \& Manning, W. J. (2014). Ozone levels in European and USA cities are increasing more than at rural sites, while peak values are decreasing. Environmental Pollution, 192, 295-299.

Pawlak, I., \& Jarosławski, J. (2015). The influence of selected meteorological parameters on the concentration of surface ozone in the central region of Poland. Atmosphere-Ocean, 53(1), 126-139.

Penkett, S. A., \& Brice, K. A. (1986). The spring maximum in photo-oxidants in the Northern Hemisphere troposphere. Nature, 319(6055), 655-657.

Raddatz, R. L., \& Cummine, J. D. (2001). Temporal surface ozone patterns in urban Manitoba. Canada. BoundaryLayer Meteorology, 99(3), 411-428.

Ramos, Y., Requia, W. J., St-Onge, B., Blanchet, J. P., Kestens, Y., \& Smargiassi, A. (2018). Spatial modeling of daily concentrations of ground-level ozone in Montreal, Canada: A comparison of geostatistical approaches. Environmental Research, 166, 487-496.

Randall, S. (2008). Baseline assessment of short-lived climate pollutants in Bangladesh. In Proceedings of 3rd International Conference on Environmental Aspects of Bangladesh (p. 33)

Retama, A., Baumgardner, D., Raga, G. B., McMeeking, G. R., \& Walker, J. W. (2015). Seasonal trends in black carbon properties and co-pollutants in Mexico City. Atmospheric Chemistry \& Physics Discussions, 15(8), 12539-12582.

Saito, S., Nagao, I., \& Tanaka, H. (2002). Relationship of NOx and $\mathrm{NMHC}$ to photochemical $\mathrm{O}_{3}$ production in a coastal and metropolitan areas of Japan. Atmospheric Environment, 36(8), 1277-1286.

Scovronick, N., Dora, C., Fletcher, E., Haines, A., \& Shindell, D. (2015). Reduce short-lived climate pollutants for multiple benefits. The Lancet, 386(10006), e28-e31.

Seinfeld, J. H. (1986). ES\&T books: Atmospheric chemistry and physics of air pollution. Environmental Science \& Technology, 20(9), 863-863.
Shan, W., Yin, Y., Lu, H., \& Liang, S. (2009). A meteorological analysis of ozone episodes using HYSPLIT model and surface data. Atmospheric Research, 4(93), 767-776.

Shindell, D., Kuylenstierna, J. C., Vignati, E., van Dingenen, R., Amann, M., Klimont, Z., et al. (2012). Simultaneously mitigating near-term climate change and improving human health and food security. Science, 335(6065), 183-189.

Sillman, S. (1999). The relation between ozone, NOx and hydrocarbons in urban and polluted rural environments. Atmospheric Environment, 33(12), 1821-1845.

Sotoudeheian, S., \& Arhami, M. (2014). Estimating groundlevel PM 10 using satellite remote sensing and groundbased meteorological measurements over Tehran. Journal of Environmental Health Science and Engineering, 12(1), $1-13$.

Sousa, S. I. V., Martins, F. G., Alvim-Ferraz, M. C. M., \& Pereira, M. C. (2007). Multiple linear regression and artificial neural networks based on principal components to predict ozone concentrations. Environmental Modelling \& Software, 22(1), 97-103.

Stevenson, D. S., Dentener, F. J., Schultz, M. G., Ellingsen, K., Van Noije, T. P. C., Wild, O., et al. (2006). Multimodel ensemble simulations of present-day and near-future tropospheric ozone. Journal of Geophysical Research: Atmospheres, 111(D8), 1-23.

Stohl, A., Aamaas, B., Amann, M., Baker, L., Bellouin, N., Berntsen, T. K., Boucher, O., Cherian, R., Collins, W., Daskalakis, N., \& Dusinska, M. (2015). Evaluating the climate and air quality impacts of short-lived pollutants. Atmospheric Chemistry and Physics, 15(18), 10529-10566.

Sudo, K., \& Akimoto, H. (2007). Global source attribution of tropospheric ozone: Long-range transport from various source regions. Journal of Geophysical Research: Atmospheres, 112(12), 1.

Szulejko, J. E., Adelodun, A. A., Kim, K. H., Seo, J. W., Vellingiri, K., Jeon, E. C., et al. (2018). Short and long-term temporal changes in air quality in a seoul urban area: The weekday/sunday effect. Sustainability, 10(4), 1248.

Turner, M. C., Jerrett, M., Pope, C. A., III., Krewski, D., Gapstur, S. M., Diver, W. R., et al. (2016). Long-term ozone exposure and mortality in a large prospective study. American Journal of Respiratory and Critical Care Medicine, 193(10), 1134-1142.

USEPA (1997). United States Environmental Protection Agency. (1993). Analysis of the Impacts of Control Programs on Motor Vehicle Toxic Emissions and Exposure Nationwide (Vol. IUS). Environmental Protection Agency.

USEPA, Air Quality Index, AQI. (2011). A Guide to Air Quality and Your Health. 9 December 2011. Retrieved 8 August 2012.

Worden, H. M., Deeter, M. N., Frankenberg, C., George, M., Nichitiu, F., Worden, J., et al. (2013). Decadal record of satellite carbon monoxide observations. Atmospheric Chemistry and Physics, 13(2), 837-850.

World Health Organization. (2003). Health aspects of air pollution with particulate matter, ozone and nitrogen dioxide: report on a WHO working group, Bonn, Germany 13-15 January 2003 (No. EUR/03/5042688). Copenhagen: WHO Regional Office for Europe 
Xue, L. K., Wang, T., Gao, J., Ding, A. J., Zhou, X. H., Blake, D. R., et al. (2014). Ground-level ozone in four Chinese cities: Precursors, regional transport and heterogeneous processes. Atmospheric Chemistry and Physics, 14(23), 13175-13188.

Zeng, G., Pyle, J. A., \& Young, P. J. (2008). Impact of climate change on tropospheric ozone and its global budgets. Atmospheric Chemistry and Physics, 8(2), 369-387.
Zhang, K., Xu, J., Huang, Q., Zhou, L., Fu, Q., Duan, Y., \& Xiu, G. (2020). Precursors and potential sources of ground-level ozone in suburban Shanghai. Frontiers of Environmental Science \& Engineering, 14, 1-12.

Publisher's Note Springer Nature remains neutral with regard to jurisdictional claims in published maps and institutional affiliations. 